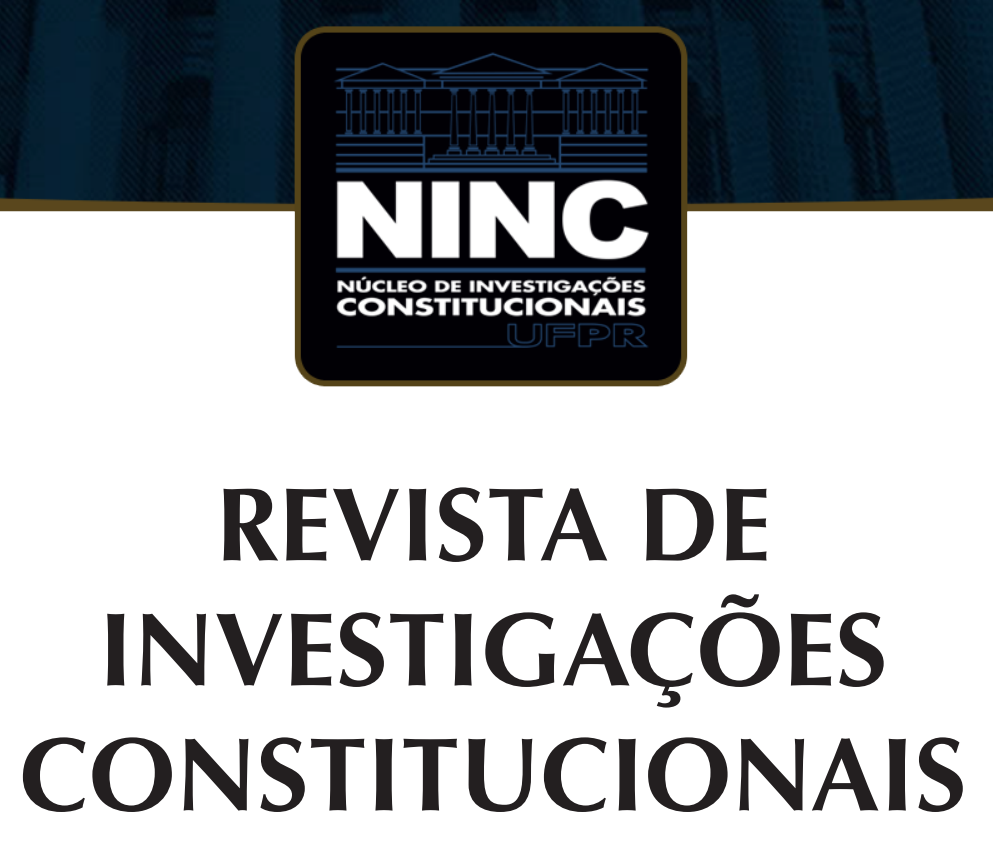

JOURNAL OF CONSTITUTIONAL RESEARCH

vol. 6 | n. 3 | setembro/dezembro 2019 | ISSN 2359-5639 | Periodicidade quadrimestral Curitiba | Núcleo de Investigações Constitucionais da UFPR | www.ninc.com.br 


\section{La arquitectura administrativa de la transparencia en España: regulation-inside-government y diseño institucional de las Autoridades de Transparencia}

\section{The administrative architecture of transparency in Spain: Regulation- inside-government and institutional design of Transparency Authorities}

\section{ENDRIUS COCCIOLO ${ }^{1, *}$}

' Universitat Rovira i Virgili (Tarragona, España) endrius.cocciolo@urv.cat https://orcid.org/0000-0003-1982-6147

Recebido/Received: $19.08 .2019 /$ August $19^{\text {th }}, 2019$ Aprovado/Approved: 25.12.2019/ December 25 st', 2019

\section{Resumen}

El presente trabajo parte de la premisa que la proliferación de leyes y autoridades de transparencia es una de las manifestaciones del creciente enfoque regulatorio aplicado al propio sector público conocido como regulation-inside-government. El auge de esta arquitectura administrativa ostenta además un importante valor constitucional. En el presente trabajo se lleva a cabo un estudio pormenorizado del diseño institucional de las autoridades de transparencia, tanto a nivel estatal como autonómico, con el fin de determinar los elementos que pueden favorecer su independencia e imparcialidad. Para comprobar si el despliegue de estas autoridades se encuadra en el marco teórico de la regulation-inside-government, en el artículo se han analizado tres ejes fundamentales: la naturaleza jurídica de la autoridad; la composición de la autoridad y el estatuto de los miembros que ocupan sus órganos rectores, especialmente cuando son competentes para resolver las reclamaciones
Abstract:

This article is based on the premise that the proliferation of transparency laws and authorities is one of the manifestations of the growing regulatory approach applied to the public sector itself known as regulation-insidegovernment. The rise of this administrative architecture also has an important constitutional value. In the present work, a detailed study of the institutional design of transparency authorities is carried out, both at national and sub-national level, in order to determine the elements that may favour their independence and impartiality. To check whether the deployment of these authorities is framed within the theoretical framework of regulation-inside-government, the article has analysed three fundamental axes: the legal nature of the authority; the composition of the authority and the statute of the members serving at its governing bodies, especially when they are competent to resolve complaints regarding access to public information; and the provision of effective resources for the fulfilment of their functions. The

Como citar esse artigo/How to cite this article: COCCIOLO, Endrius. La arquitectura administrativa de la transparencia en España: regulation-inside-government y diseño institucional de las Autoridades de Transparencia. Revista de Investigações Constitucionais, Curitiba, vol. 6, n. 3, p. 521-571, set./dez. 2019. DOI: 10.5380/rinc.v6i3.68602.

* Profesor Agregado de Derecho Administrativo, Departamento de Derecho Público de la Universitat Rovira i Virgili (Tarragona, España). Doctor en Relaciones Internacionales e Integración Europea por la Universitat Autònoma de Barcelona (UAB), Postdoctor en Derecho por la Fordham University de New York; Director del Master Interuniversitario en Derecho de la Administración Pública de la URV y la Universidad de Zaragoza. E-mail: endrius.cocciolo@urv.cat. 
en materia de acceso a la información pública; y la disposición de recursos efectivos para el cumplimiento de sus funciones. Los resultados del análisis evidencian que - más allá de la heterogeneidad de las fórmulas empleadas por los legisladores - existen requisitos necesarios y elementos que correctamente empleados pueden influir en la independencia de las autoridades de transparencia.

Palabras clave: Autoridades de transparencia; consejos de transparencia; independencia y autonomía; reclamación y derecho de acceso; regulation-inside-government. results of the analysis show that, beyond the heterogeneity of the formulas used by legislators, there are necessary requirements and elements that correctly employed can influence the independence of the transparency authorities.

Keywords: Transparency authorities; transparency councils; independence and autonomy; complaint and right of access; regulation-inside-government.

\section{SUMARIO}

1. Planteamiento: la relevancia de las autoridades de transparencia en el marco de la regulation-inside-government; 2. Metodología y delimitación del ámbito material de estudio; 3. Naturaleza jurídica de las autoridades de control y protección de la transparencia; 3.1. Autoridades de Transparencia como Autoridades Administrativas Independientes; 3.2. Autoridades de Transparencia como órganos adscritos a la Administración o al Parlamento autonómico; 3.3. Autoridades de transparencia vinculadas a los Defensores del Pueblo; 4. Composición de las autoridades de transparencia y estatuto de los miembros de sus órganos rectores; 4.1. Carácter unipersonal o colegiado y su relevancia; 4.2. Composición de las autoridades de transparencia; 4.3. Forma de designación de los miembros de las autoridades de transparencia; 4.4. La inamovilidad del cargo y la tasación de los supuestos de cese de los miembros de las autoridades de trasparencia; 4.5. Mandatos, dedicación e incompatibilidades de los miembros de las autoridades de transparencia; $\mathbf{5}$. Medios económicos, materiales y personales de las autoridades de transparencia; 5.1. Medios económicos y gestión presupuestaria; 5 .2. Medios personales; 6 . Reflexiones conclusivas; 7. Referencias.

\section{PLANTEAMIENTO: LA RELEVANCIA DE LAS AUTORIDADES DE TRANSPARENCIA EN EL MARCO DE LA REGULATION-INSIDE- -GOVERNMENT.}

Vivimos tiempos difíciles: por el impacto de las crisis económicas y las medidas de austeridad en los menguantes derechos sociales; por la intensificación de las crisis humanitarias, la creciente vulneración de derechos fundamentales y el afianzamiento de movimientos de extrema derecha y nacionalpopulistas; por el estado de emergencia ecológica planetaria de origen antrópico y su negacionismo por gobiernos capturados por intereses corporativos; por la erosión de la legitimidad democrática de los poderes públicos y la consecuente desafección ciudadana. Todos estos factores aumentan y empeoran en un entorno infectado por la corrupción, por este motivo urgen medidas para fomentar la regeneración, la calidad y la sostenibilidad democrática'. Esta tarea, en pa-

\footnotetext{
Sobre esta necesidad, véase por ejemplo las reflexiones de: FUENTES I GASÓ, Josep Ramon. La función de regeneración democrática local de los funcionarios de habilitación con carácter nacional. Revista de Estudios de la Administración Local y Autonómica, Madrid, n. 4, p. 9-39, jul./dic. 2015; LEAL, Rogério Gesta. Estado,
} 
labras de Gimeno Feliu, interpela a un “Derecho Público garantista, moderno, vinculado al derecho a la buena administración, [y] aconseja reforzar los mecanismos de control de naturaleza preventiva mediante la necesaria independencia de un control efectivo y rápido"2 ${ }^{2}$ La lucha contra la corrupción ${ }^{3}$ y su prevención requieren una nueva cultura de gobernanza pública "cimentada en los principios de integridad y transparencia"4. La conexión entre estos principios y los mecanismos de control independientes remite a la idea de "regulación", cuya centralidad e importancia en la redefinición del Estado ha sido evidenciada por Ballbé y Martínez en su análisis de la evolución del "administrative governement" al "regulatory governement"

En este ámbito, la doctrina ha evidenciado que la idea más tradicional de regulación - aquella que se refiere a la "regulación de sectores económicos", mediante autoridades independientes públicas y/o a través de los propios sujetos privados (self regulation $^{6}$ ) - representa, sin embargo, sólo una visión parcial del fenómeno "regulación". En efecto, también se pude hablar de regulación del propio aparato público ("regulation-inside-government"), a la luz de su importante y cada vez más extenso desarrollo?. Los estudiosos que han analizado con más atención el fenómeno han apuntado que "the word regulation in not generally used to denote the various ways in which public organizations are shaped by rules and standards emanating from arm's-lenght autorithies" ${ }^{\prime \prime}$.

En el presente estudio se empleará este marco teórico con el fin de analizar la arquitectura administrativa de la transparencia en España, constituida por el conjunto heterogéneo de Consejos, Comisiones y Comisionados a los que se han encomendado funciones de control y a los que nos referiremos bajo el rótulo genérico de "autoridades

democracia e corrupção: equações complexas. Revista de Investigações Constitucionais, Curitiba, vol. 6, n. 1, p. 91-106, jan./abr. 2019; LEAL, Rogério Gesta. Corrupção, democracia e mercado: horizontes turvos. Revista de Direito Econômico e Socioambiental, Curitiba, v. 8, n. 2, p. 303-329, maio/ago. 2017.

2 GIMENO FELIU, José Maria. Corrupción y seguridad jurídica. La necesidad de un marco normativo de las decisiones públicas anclado en los principios de integridad y transparencia. Revista Internacional de Transparencia e Integridad, Madrid, n. 9, p. 3. ene./abr. 2019.

3 FORTINI, Cristiana; SHERMAM, Ariane. Corrupção: causas, perspectivas e a discussão sobre o princípio do bis in idem. Revista de Investigações Constitucionais, Curitiba, vol. 5, n. 2, p. 91-112, maio/ago. 2018.

4 GIMENO FELIU, José Maria. Corrupción y seguridad jurídica. La necesidad de un marco normativo de las decisiones públicas anclado en los principios de integridad y transparencia. Revista Internacional de Transparencia e Integridad, Madrid, n. 9, p. 4. ene./abr. 2019; RODRÍGUEZ-ARANA MUÑOZ, Jaime. La

Directiva Europea de Contratación Pública y la lucha contra la corrupción. Revista de Direito Econômico e Socioambiental, Curitiba, v. 8, n. 1, p. 24-56, jan/abr. 2017.

5 BALLBÉ, Manuel; MARTíNEZ, R. Law and Globalization: Between the United States and Europe. In ROBALINO-ORELLANA, Javier; RODRÍGUEZ-ARANA MUÑOZ, Jaime (Eds.) Global Administrative Law. Towards a Lex Administrativa. Cameron: Cameron May, 2010, p. 155.

6 BARTLE, Ian; VASS, Peter. "Self-Regulation within the Regulatory State: Towards a New Regulatory Paradigm? Public Administration, v. 85, n. 4, p. 885-905, oct./dez. 2007.

7 HOOD, Christopher, JAMES, Oliver, JONES, George, SCOTT, Colien, TRAVERS, Tony. Regulation Inside Government. Waste Watchers, Quality Police, and Sleaze-busters. Oxford: Oxford University Press, 1999, p. 4.

8 HOOD, Christopher, JAMES, Oliver, JONES, George, SCOTT, Colien, TRAVERS, Tony. Regulation Inside Government. Waste Watchers, Quality Police, and Sleaze-busters. Oxford: Oxford University Press, 1999, p. 4. 
de transparencia". La actividad llevada a cabo por estas autoridades constituye una función de control (oversight) ${ }^{9}$ que ostenta un claro valor constitucional ${ }^{10}$. Se puede añadir que las cuestiones inherentes al objeto de la regulation-inside-government atañen al núcleo duro de la teoría democrática en la medida en que "[...] a central concern is to secure that those in power remain faithful to de mandate given them by the electorate and ensure that they keep within the rules of the game"11.

La doctrina considera que en las democracias modernas el control de los poderes públicos se lleva a cabo mediante dos clases de mecanismos: la primera comprende los mecanismos de "vertical accountability", mediante los cuales la ciudadanía directamente elige o castiga sus representantes; la segunda engloba, en cambio, un conjunto de mecanismos de "horizontal accountability" que se dirigen a la supervisión y control de las actividades y de los cargos públicos y mediante la creación de una compleja arquitectura de organismos de supervisión y control. Debe observarse que las autoridades reguladoras del propio sector público responden a necesidades diferentes respecto a los reguladores de los mercados, tales como: asegurar la responsabilidad económica de los entes y administradores públicos, velar por la buena administración y los derechos de los ciudadanos frente a los poderes públicos, promover y fortalecer la integridad pública. En palabras de Kaye: "there is now a considerable 'regulatory state within the state' and it seems to be growing"12.

El auge de las autoridades de regulación de los poderes públicos queda manifiesto en la proliferación de autoridades de transparencia que ha tenido lugar en España desde el 2013, año en el que se aprobó la primera ley específica en esta materia ${ }^{13}$ y se instituyó el Consejo de Transparencia y Buen Gobierno.

\footnotetext{
9 HARDEN, Ian. Regulating Government, The Political Quartely, London, v. 66, Issue 4, p. 299-306, oct./dez. 1995.

10 SCOTT, Colin. Accountability in the Regulatory State. Journal of Law and Society, London, v. 27, Issue 1, p. 38-60, jan./jul. 2000.

11 MULGAN, Richard. Holding power to account: accountability in modern democracies. Basingstoke: Palgrave Macmillan, 2003.

12 KAYE, Robert. Regulating Parliament: the regulatory state within Westminster. Discussion Paper 13, Centre for Analysis of risk and regulation, LSE, p. 1, Jun. 2003. Disponible on line: http://eprints.Ise.ac.uk/35999/1/ Disspaper13.pdf.

13 Sobre el tema, ex multis, véase: RODRÍGUEZ-ARANA MUÑOZ, Jaime; SENDÍN GARCÍA, Miguel Ángel. Transparencia, acceso a la información y buen gobierno. Comentarios a la Ley 19/2013, de 9 de diciembre, de Transparencia, Acceso a la Información Pública y buen gobierno. Granada: Comares, 2014. BLANES CLIMENT, Miguel Ángel. La Transparencia informativa de las administraciones públicas: el derecho de las personas a saber y la obligación de difundir información pública de forma activa. Navarra: Thomson Reuters Aranzadi, 2014; GUICHOT, Emilio (Coord). Transparencia, acceso a la información pública y buen gobierno. Estudio de la Ley 19/2013, de 9 de diciembre. Madrid: Tecnos, 2014; VALERO TORRIJOS, Julián, FERNÁNDEZ SALMERÓN, Manuel (Coords). Régimen jurídico de la transparencia en el sector público: del derecho de acceso a la reutilización de la información. Navarra: Thomson Reuters Aranzadi, 2014; BERMEJO LATRE, José Luis, CASTEL GAYÁN, Sergio (Eds.) Transparencia, participación ciudadana y administración pública en el siglo XXI. Zaragoza: Gobierno de Aragón, Departamento de Hacienda y Administración Pública, 2013; MESEGUER YEBRA, Joaquín. La Transparencia en las administraciones públicas: el procedimiento de
} 
Sin embargo, para que pueda hablarse propiamente de regulation-inside-government, la doctrina ha destacado la necesidad de que se cumplan los siguientes tres requisitos ${ }^{14}$ : (1) la existencia de "[o]ne bureaucracy aims to shape the activities of another; (2) [S]ome degree of organizational separation between the 'regulating' bureaucracy and the 'regulatee'; y finalmente es necesario que (3) "[t] he 'regulator' has some kind of official mandate to scrutinize the behavior of the 'regulatee' and seek to change it". Por otra parte, las razones que justifican la atribución de potestades de supervisión y control a unos organismos reguladores independientes, son las mismas tanto en el caso de la regulación de los mercados como de la regulation-inside-government, y se fundamentan en el reconocimiento de la independencia y la expertise para lograr una mayor credibilidad y eficiencia de las políticas públicas.

La adopción en España, desde el 2013 hasta el 2019, de una serie de normas con rango legislativo y reglamentario, a nivel estatal y autonómico, dirigidas tanto a regular la transparencia - en su dimensión de publicidad activa como de derecho de acceso a la información pública - así como a crear una serie autoridades para el control del cumplimiento de dicha normativa, satisface el tercer criterio señalado - el mandato explícito - para que se pueda hablar de regulation-inside-government. En las páginas que siguen se tratará de averiguar si también se cumplen los otros dos criterios, ya que sin especialización, efectividad e independencia no hay regulación que garantice la transparencia ${ }^{15}$.

El cumplimiento de la misión institucional de las autoridades de transparencia depende, en primer lugar, de su configuración normativa. En efecto, el dato normativo no sólo predetermina su ámbito de actuación, sino que la manera de llevar a cabo las funciones que tienen atribuidas depende de cómo en dichas autoridades se plasman

acceso a la información pública. Barcelona: Bosch, 2013; PIÑAR MAÑAS, José Luis, Transparencia y derecho de acceso a la información pública: algunas reflexiones en torno al derecho de acceso en la Ley 19/2013, de transparencia, acceso a la información y buen gobierno. Revista Catalana de Dret Públic, Barcelona, n. 49, p. 1-19, oct./dic. 2014; REY MARTÍNEZ, Fernando. Quod omnes tangit ab omnibus cognitum esse debet: el derecho de acceso a la información pública como derecho fundamental. Revista Jurídica de Castilla y León, Valladolid, n. 33, p. 1-19, mai 2014; VELASCO RICO, Clara. La cuestión competencial en la Ley 19/2013, de 9 de diciembre: ¿de qué margen disponen las CC.AA. en materia de transparencia, acceso a la información pública y buen gobierno? Revista jurídica de Castilla y León, Valladolid, n. 33, p. 1-34, mai. 2014. Sobre el acceso a la información pública en países latinoamericanos, véase: VALIM, Rafael. El derecho fundamental de acceso a la información pública en el Derecho brasileño. Revista de Investigações Constitucionais, Curitiba, vol. 3, n. 1, p. 169-181, jan./abr. 2016; PERLINGEIRO, Ricardo; DÍAZ, Ivonne; LIANI, Milena. Princípios sobre o direito de acesso à informação oficial na América Latina. Revista de Investigações Constitucionais, Curitiba, vol. 3, n. 2, p. 143-197, maio/ago. 2016.

14 HOOD, Christopher, JAMES, Oliver, JONES, George, SCOTT, Colien, TRAVERS, Tony. Regulation Inside Government. Waste Watchers, Quality Police, and Sleaze-busters. Oxford: Oxford University Press, 1999, p. 8.

15 BELARRA GORROCHATEGUI, Javier. Los consejos de transparencia autonómicos en España: ¿Marketing político o vectores de buen gobierno? Revista Internacional de Transparencia e Integridad, Barcelona, n. 6, p. 12, ene./abr. 2018. 
los principios de independencia y autonomía que inspiran su creación ${ }^{16}$. Una configuración institucional que garantice la independencia de las autoridades de transparencia no es una cuestión solo deseable o meramente estética, sino que constituye - cómo veremos - un requisito legal imprescindible, además de convertirse en un elemento fundamental para considerar estas instancias como mecanismos alternativos a las vías jurisdiccionales clásicas, puesto que su validez estará en función del reconocimiento y credibilidad que las partes involucradas les otorguen ${ }^{17}$. Estas garantías se requieren, además, por el derecho internacional: el Convenio del Consejo de Europa sobre Acceso a los Documentos Públicos ${ }^{18}$ establece que los estados firmantes deberán contar con "un procedimiento de reclamación ante un tribunal u otra institución independiente e imparcial establecida por la ley" (art. 8).

Como tendremos oportunidad de demostrar en las páginas siguientes, la independencia y plena autonomía de las Autoridades de Transparencia no viene determinado por un solo factor organizativo o de diseño institucional, sino por el conjunto de todos ellos. En este sentido, conviene apuntar que a menudo se ha incidido sobremanera en la personalidad jurídica propia de los organismos de control, obviando que la misma puede ser una condición deseable, pero en ningún caso necesaria ni suficiente, para garantizar su autonomía, la cual es un producto más de su configuración material que de su denominación formal ${ }^{19}$.

\section{METODOLOGÍA Y DELIMITACIÓN DEL ÁMBITO MATERIAL DE ESTUDIO.}

En las siguientes epígrafes se desarrolla un análisis sistemático de tres elementos del diseño de las autoridades de transparencia - tanto la estatal como las autonómicas - que inciden en su independencia: 1) La naturaleza jurídica de la autoridad; 2) La composición de las autoridades y el estatuto de los miembros que ocupan sus órganos rectores; 3) La disposición de medios para el desarrollo de las funciones que tienen

\footnotetext{
16 MARTÍN DELGADO, Isaac. La reclamación ante el Consejo de Transparencia y Buen Gobierno: un instrumento necesario, útil y ¿eficaz? In: LÓPEZ RAMÓN, Fernando (Coord.). Las vías administrativas de recurso a debate, Madrid, p. 291-328, jan./mai. 2016.

17 RAMS RAMOS, Leonor. Las medidas alternativas de resolución de conflictos en el ámbito de la transparencia. In: CÁMARA, Pablo Chico de la (Dir.), Una propuesta para la introducción en nuestro sistema administrativo y tributario de medidas alternativas de resolución de conflictos (ADR), Madrid, p. 169-210, jan./ mai. 2017.

18 COTINO HUESO, Lorenzo. El reconocimiento y contenido internacional del acceso a la información pública como derecho fundamental. In: UNED. Teoría y Realidad Constitucional, Barcelona, n. 40, p. 279-316, jan./ mai. 2017.

19 JIMÉNEZ ASENSIO, Rafael. Instituciones de garantía de la transparencia. El Cronista Del Estado Social y Democrático de Derecho, Madrid, n. 68, p. 67, 2017; MARTín DELGADO, Isaac. La configuración legal de los consejos autonómicos de transparencia: algunos riesgos para el ejercicio de su función de control. Dilemata, Madrid, n. 27, p. 288-289, abr. 2018.
} 
encomendadas. Por lo tanto, desde un punto de vista metodológico, en el presente trabajo se analizan autoridades de transparencia exclusivamente en términos de diseño normativo de las mismas, valorando en qué medida las disposiciones reguladoras de cada una de ellas y la resultante arquitectura institucional favorecen o dificultan la autonomía efectiva del órgano o entidad. En consecuencia, el objeto del estudio excluye conscientemente aspectos vinculados al rendimiento y desempeño operativo de tales autoridades.

En el análisis que se desarrollará en este artículo se tendrá en consideración además del Consejo de Transparencia y Buen Gobierno (CTBG) estatal, creado por la Ley 19/2013, de 9 de diciembre, de transparencia, acceso a la información pública y buen gobierno (LTBG), las autoridades con funciones análogas creadas en las Comunidades Autónomas españolas. En dicho nivel sub-estatal pueden observarse tres situaciones en relación con la existencia de leyes autonómicas de transparencia y autoridades de transparencia propias.

En primer lugar, hay que contemplar la situación de inexistencia de una normativa de transparencia propia, como ocurre en el caso del País Vasco. En dicha comunidad, existe un proyecto de ley de transparencia en tramitación desde hace tiempo ${ }^{20}$; sin embargo, el ejecutivo autonómico ha creado la Comisión Vasca de Acceso a la Información Pública (CVAIP) con las funciones propias y plenamente equiparables a las de una autoridad de transparencia. En este sentido la exposición de motivos del Decreto 128/2016 por el que se crea la CVAIP, afirma que mediante dicha norma "se desarrolla en el ámbito de la Comunidad Autónoma de Euskadi el esquema operativo esencial de la [LTBG] [...]"y añade que "[s]e pretende, en puridad, cumplimentar una opción revestida de cierta provisionalidad, pero que bien puede hacer convivir desde ahora la satisfacción del interés público que es necesario atender con la esperable consideración de este asunto desde la estabilidad que proporcionaría la regulación en una norma con rango de Ley". Por este motivo se puede incluir dicho organismo en el presente análisis.

El análisis abarca un segundo grupo de Comunidades Autónomas, claramente mayoritario, en las cuales se han aprobado Leyes de Transparencia propias. Las Comunidades Autónomas pertenecientes a este grupo se han dotado de autoridades de transparencias específicas o han atribuido sus competencias a un organismo ya existente en su ámbito territorial. Finalmente, un tercer supuesto es aquel que atañe Comunidades Autónomas que, a pesar de disponer de una Ley de Transparencia propia, han optado por atribuir al CTBG estatal (mediante la suscripción de un convenio de colaboración) la resolución de las reclamaciones de acceso a la información pública, tal como faculta

20 Para más informaciones sobre la normativa vasca en elaboración: http://www.euskadi.eus/gobierno-vasco/-/proyecto-ley/04-ley-de-transparencia-participacion-ciudadana-y-buen-gobierno/ 
la Disposición Adicional 4.2 LTBG. Esta opción ha sido elegida por las Comunidades Autónomas de Extremadura y La Rioja²1.

Por último, hay casos en los cuales la Ley de Transparencia de la Comunidad Autónoma contempla la existencia de una autoridad autonómica propia, si bien la misma aún no ha sido creada y, en consecuencia, se atribuyen temporalmente la resolución de las reclamaciones al CTBG. Este supuesto se da, por ejemplo, en el Principado de Asturias, en Cantabria y Comunidad de Madrid. En esta última, la reciente Ley 10/2019, de 10 de abril, de Transparencia y Participación de la Comunidad de Madrid (LTM) prevé que hasta que no entre en funcionamiento su Consejo de Transparencia y Participación (CTPM), las reclamaciones contra las resoluciones de denegación de acceso a la información contra actos de la Comunidad Autónoma de Madrid se regirán por lo establecido en la Disposición Transitoria segunda de la Ley 5/2016 de la Comunidad de Madrid y, por ende, corresponderán al CTBG estatal. Estos supuestos también sarán objeto de análisis, considerando que el presente estudio se limita al análisis de la arquitectura institucional y no a la evaluación de la actividad realizada por las autoridades en cuestión.

\begin{tabular}{|l|c|c|c|}
\hline \multicolumn{4}{|c|}{ TABLA 1. LEYES Y AUTORIDADES DE TRANSPARENCIA } \\
\hline Ley estatal de transparencia: & $\begin{array}{c}\text { Acrónimo } \\
\text { utilizado (leyes) }\end{array}$ & $\begin{array}{c}\text { Autoridades de } \\
\text { Transparencia }\end{array}$ & $\begin{array}{c}\text { Acrónimo } \\
\text { utilizado } \\
\text { (autoridades) }\end{array}$ \\
\hline $\begin{array}{l}\text { Ley 19/2013, de 9 de diciembre, } \\
\text { de transparencia, acceso a la } \\
\text { información pública y buen gobierno }\end{array}$ & LTBG & $\begin{array}{c}\text { Consejo de } \\
\text { Transparencia } \\
\text { y Buen Gobierno }\end{array}$ & CTBG \\
\hline $\begin{array}{l}\text { Leyes autonómicas de } \\
\text { transparencia } \\
\text { (orden cronológico): }\end{array}$ & & & \\
\hline
\end{tabular}

21 En el caso de Extremadura, su Ley de Gobierno Abierto no regula ninguna autoridad de transparencia autonómica. El art. 25 de la LGAEx remite a la legislación básica del Estado en el caso de reclamaciones frente a toda resolución expresa o presunta en materia de acceso dictada de conformidad con el procedimiento regulado en la LGAEx, así como frente a la resolución de los recursos administrativos que contra aquella sean procedentes, con carácter potestativo y previo a la impugnación en vía contencioso-administrativa.

En el caso de La Rioja, tampoco se crea ninguna autoridad específica para la resolución de las reclamaciones en materia de acceso, afirmando la competencia del CTBG estatal para conocer de las mismas (art. 16).

La información sobre las autoridades autonómicas de transparencia o sobre los convenios con el CTBG, se puede consultar en la página web del propio CTBG: http://www.consejodetransparencia.es/ct_Home/transparencia/transparencia-en-espanya.html. 


\begin{tabular}{|c|c|c|c|c|}
\hline 1) & $\begin{array}{l}\text { Ley } 4 / 2011 \text {, de } 31 \text { de marzo, de } \\
\text { buena administración y buen } \\
\text { gobierno de las Islas Baleares }\end{array}$ & LBAIB & $\begin{array}{c}\text { Comisión } \\
\text { para las } \\
\text { Reclamaciones } \\
\text { de Acceso a la } \\
\text { Información } \\
\text { Pública de las } \\
\text { Islas Baleares } \\
\text { (creada por el } \\
\text { Decreto } 1 / 2019 \\
\text { y no por la } \\
\text { LBAIB) }\end{array}$ & CRAIPIB \\
\hline 2) & $\begin{array}{l}\text { 2) Ley } 4 / 2013 \text {, de } 21 \text { de mayo, } \\
\text { de Gobierno Abierto de } \\
\text { Extremadura }\end{array}$ & LGAEx & -- & -- \\
\hline 3) & $\begin{array}{l}\text { Ley } 1 / 2014 \text {, de } 24 \text { de junio, } \\
\text { de Transparencia Pública de } \\
\text { Andalucía }\end{array}$ & LTAn & $\begin{array}{l}\text { Consejo de } \\
\text { Transparencia } \\
\text { y Protección } \\
\text { de Datos de } \\
\text { Andalucía }\end{array}$ & CTPDAn \\
\hline 4) & $\begin{array}{l}\text { Ley } 3 / 2014 \text {, de } 11 \text { de septiembre, } \\
\text { de Transparencia y Buen } \\
\text { Gobierno de La Rioja }\end{array}$ & LTL & -- & -- \\
\hline 5) & $\begin{array}{l}\text { Ley } 12 / 2014 \text {, de } 16 \text { de diciembre, } \\
\text { de Transparencia y Participación } \\
\text { Ciudadana de Murcia }\end{array}$ & LTMu & $\begin{array}{c}\text { Consejo de } \\
\text { Transparencia } \\
\text { de la Región de } \\
\text { Murcia }\end{array}$ & CTMu \\
\hline 6) & $\begin{array}{l}\text { Ley } 12 / 2014 \text {, de } 26 \text { de diciembre, } \\
\text { de Transparencia y de Acceso a la } \\
\text { Información Pública de Canarias }\end{array}$ & LTCn & $\begin{array}{l}\text { Comisionado de } \\
\text { Transparencia } \\
\text { y Acceso a la } \\
\text { Información } \\
\text { Pública }\end{array}$ & CTCn \\
\hline 7) & $\begin{array}{l}\text { Ley 19/2014, de } 29 \text { de diciembre, } \\
\text { de Transparencia, Acceso a la } \\
\text { Información Pública y Buen } \\
\text { Gobierno de Cataluña }\end{array}$ & LTCat & $\begin{array}{l}\text { Comisión de } \\
\text { Garantía de } \\
\text { Acceso a la } \\
\text { Información } \\
\text { Pública de } \\
\text { Cataluña }\end{array}$ & CGAIP \\
\hline 8) & $\begin{array}{l}\text { Ley } 3 / 2015 \text {, de } 4 \text { de marzo, de } \\
\text { Transparencia y Participación } \\
\text { Ciudadana de Castilla y León }\end{array}$ & $\mathrm{LTCL}$ & $\begin{array}{l}\text { Comisionado de } \\
\text { Transparencia; } \\
\text { Comisión de } \\
\text { Transparencia }\end{array}$ & $\begin{array}{l}\text { CTPC } \\
\text { CTCL }\end{array}$ \\
\hline 9) & $\begin{array}{l}\text { Ley } 8 / 2015 \text {, de } 25 \text { de marzo, de } \\
\text { Transparencia de la Actividad } \\
\text { Pública y Participación } \\
\text { Ciudadana de Aragón }\end{array}$ & LTAr & $\begin{array}{l}\text { Consejo de } \\
\text { Transparencia } \\
\text { de Aragón }\end{array}$ & CTAr \\
\hline
\end{tabular}




\begin{tabular}{|c|c|c|c|c|}
\hline 10) & $\begin{array}{l}\text { Ley } 2 / 2015 \text {, de } 2 \text { de abril, de la } \\
\text { Generalitat, de Transparencia, } \\
\text { Buen Gobierno y Participación } \\
\text { Ciudadana de la Comunidad } \\
\text { Valenciana }\end{array}$ & LTCV & $\begin{array}{c}\text { Consejo de } \\
\text { Transparencia, } \\
\text { Acceso a la } \\
\text { Información } \\
\text { Pública y Buen } \\
\text { Gobierno }\end{array}$ & CTCV \\
\hline 11) & $\begin{array}{l}\text { Ley } 1 / 2016 \text {, de } 18 \text { de enero, de } \\
\text { Transparencia y Buen Gobierno } \\
\text { de Galicia }\end{array}$ & LTGa & $\begin{array}{c}\text { Comisionado de } \\
\text { Transparencia } \\
\text { (CTVP); } \\
\text { Comisión de } \\
\text { Transparencia } \\
\text { (CTGa) }\end{array}$ & $\begin{array}{l}\text { CTVP } \\
\text { CTGa }\end{array}$ \\
\hline 12) & $\begin{array}{l}\text { Ley } 4 / 2016 \text {, de } 15 \text { de diciembre, } \\
\text { de Transparencia y Buen } \\
\text { Gobierno de Castilla-La Mancha }\end{array}$ & LTCM & $\begin{array}{l}\text { Consejo } \\
\text { Regional de } \\
\text { Transparencia } \\
\text { y Buen Gobierno }\end{array}$ & CRTCM \\
\hline 13) & $\begin{array}{l}\text { Ley } 1 / 2018 \text {, de } 21 \text { de marzo, de } \\
\text { Transparencia de la Actividad } \\
\text { Pública de Cantabria }\end{array}$ & $\mathrm{LTCb}$ & $\begin{array}{l}\text { Consejo de } \\
\text { Transparencia } \\
\text { de Cantabria } \\
\text { (previsto) }\end{array}$ & $\mathrm{CTCb}$ \\
\hline 14) & $\begin{array}{l}\text { Ley Foral 5/2018, de } 17 \text { de mayo, } \\
\text { de Transparencia, Acceso a la } \\
\text { Información Pública y Buen } \\
\text { Gobierno de Navarra }\end{array}$ & LTNv & $\begin{array}{c}\text { Consejo de } \\
\text { Trasparencia de } \\
\text { Navarra }\end{array}$ & CTNv \\
\hline 15) & $\begin{array}{l}\text { Ley } 8 / 2018 \text {, de } 14 \text { de septiembre, } \\
\text { de Transparencia, Buen Gobierno } \\
\text { y Grupos de Interés de Asturias }\end{array}$ & LTAs & $\begin{array}{l}\text { Consejo de } \\
\text { Transparencia y } \\
\text { Buen Gobierno } \\
\text { (previsto) }\end{array}$ & CTAs \\
\hline \multirow[t]{2}{*}{ 16) } & $\begin{array}{l}\text { Ley } 10 / 2019 \text {, de } 10 \text { de abril, de } \\
\text { Transparencia y Participación de } \\
\text { la Comunidad de Madrid }\end{array}$ & LTM & $\begin{array}{l}\text { Consejo de } \\
\text { Transparencia y } \\
\text { Participación }\end{array}$ & CTM \\
\hline & & & $\begin{array}{l}\text { Comisión Vasca } \\
\text { de Acceso a la } \\
\text { información } \\
\text { Pública (Creada } \\
\text { por el Decreto } \\
\text { 128/2016, de } 13 \\
\text { de septiembre) }\end{array}$ & CVAIP \\
\hline
\end{tabular}




\section{NATURALEZA JURÍDICA DE LAS AUTORIDADES DE CONTROL Y PROTECCIÓN DE LA TRANSPARENCIA}

La Disposición Adicional Cuarta ${ }^{22}$ de la LTBG, dispone que el órgano determinado en cada Comunidad Autónoma para la protección y control de la transparencia debe ser "independiente". Así todas las Leyes autonómicas proclaman el carácter independiente de sus respectivas autoridades de garantía de la transparencia, su autonomía y no sometimiento a instrucciones jerárquicas. Sin embargo, las normas autonómicas no siguen un patrón institucional único, de tal manera que la formula jurídica empleada para diseñar la autoridad puede implicar diversos niveles de garantía formal de su independencia. El análisis de las Leyes de Transparencia, ha puesto de manifiesto que las fórmulas empleadas por el legislador estatal y los legisladores autonómicos se pueden reconducir a tres modelos, a saber: 1 ) la autoridad administrativa independiente; 2) el órgano adscrito a la administración o al parlamento autonómico y 3) la autoridad de transparencia vinculada al defensor del pueblo. A continuación se analizarán los rasgos característicos de cada modelo.

\subsection{Autoridades de Transparencia como Autoridades Administrati- vas Independientes}

La ley estatal y la andaluza han optado por crear entes públicos diferenciados dotados de especial autonomía. En el primer supuesto, el CTBG ha sido configurado por legislador estatal como autoridad administrativa independiente (art. 33.1 LTBG) y forma parte del sector público institucional estatal ${ }^{23}$. En la Ley 40/2015, de 1 de octu-

22 Disposición adicional cuarta. Reclamación:

"1. La resolución de la reclamación prevista en el artículo 24 corresponderá, en los supuestos de resoluciones dictadas por las Administraciones de las Comunidades Autónomas y su sector público, y por las Entidades Locales comprendidas en su ámbito territorial, al órgano independiente que determinen las Comunidades Autónomas.

No obstante lo dispuesto en el párrafo anterior, contra las resoluciones dictadas por las Asambleas Legislativas y las instituciones análogas al Consejo de Estado, Consejo Económico y Social, Tribunal de Cuentas y Defensor del Pueblo en el caso de esas mismas reclamaciones sólo cabrá la interposición de recurso contencioso-administrativo.

2. Las Comunidades Autónomas podrán atribuir la competencia para la resolución de la reclamación prevista en el artículo 24 al Consejo de Transparencia y Buen Gobierno. A tal efecto, deberán celebrar el correspondiente convenio con la Administración General del Estado, en el que se estipulen las condiciones en que la Comunidad sufragará los gastos derivados de esta asunción de competencias.

3. Las Ciudades con Estatuto de Autonomía podrán designar sus propios órganos independientes o bien atribuir la competencia al Consejo de Transparencia y Buen Gobierno, celebrando al efecto un Convenio en los términos previstos en el apartado anterior."

23 Art.84.1.b) de la Ley 40/2015, de 1 de octubre, de Régimen Jurídico del Sector Público (LRJSP). Cabe añadir que el CTBG estatal está catalogado en el Inventario de Entes del Sector Público Estatal con el código OE154 como Autoridad administrativa independiente, junto con la Agencia Española de Protección de Datos, la Comisión de los Mercados y la Competencia, la Comisión Nacional de Mercado de Valores y el Consejo de Seguridad Nuclear. 
bre, de Régimen Jurídico del Sector Público (LRJSP) se definen como autoridades administrativas independientes de ámbito estatal "las entidades de derecho público que, vinculadas a la Administración General del Estado y con personalidad jurídica propia, tienen atribuidas funciones de regulación o supervisión de carácter externo sobre sectores económicos o actividades determinadas, por requerir su desempeño de independencia funcional o una especial autonomía respecto de la Administración General del Estado, lo que deberá determinarse en una norma con rango de Ley" (art. 109.1 LRJSP). Dichas autoridades se rigen por su legislación específica y, supletoriamente y en cuanto sea compatible con su naturaleza y autonomía, por lo dispuesto en la LRJSP, y demás normas de derecho administrativo general y especial que les sean de aplicación, tal como establece el art. 110 LRSJP. En consecuencia, las autoridades administrativas independientes están configuradas para garantizar que el poder ejecutivo carezca sobre las mismas de las funciones de dirección y control, de iure o de facto, que caracterizan su relación con la mayoría de la administración institucional instrumental ${ }^{24}$. Debe observarse que el CTBG está adscrito al Ministerio de Hacienda y Administraciones Públicas (art. 33.1 LTBG). En la doctrina se ha criticado esta circunstancia en la medida en que se adscribe el Consejo en una de las estructuras que está llamado a controlar ${ }^{25}$. Además del Ministerio al que se adscribe depende la asignación presupuestaria para el funcionamiento del CTBG, lo que podría influir negativamente en su autonomía de funcionamiento ${ }^{26}$. A pesar de que la adscripción no es en sí misma determinante de la autonomía e independencia del CTBG, otra fórmula, como la adscripción a las Cortes generales ${ }^{27}$ hubiera resultado una solución más garantista de su autonomía formal respecto del poder ejecutivo, especialmente a raíz del ejercicio del control de legalidad cuasi-judicial en relación a las reclamaciones planteadas en el ejercicio del derecho de acceso a la información pública ${ }^{28}$. No falta, sin embargo, la opinión de la doctrina que

\footnotetext{
24 SIERRA RODRÍGUEZ, Javier. Una crítica al diseño de los organismos de garantía del derecho de acceso en las comunidades autónomas. Revista Jurídica de Castilla y León, Valladolid, n. 45, p. 81-82, mai. 2018.

25 GARCÍA COSTA, Francisco Manuel. El Consejo de Transparencia y Buen Gobierno. VALEROTORRIJOS, Julián, FERNÁNDEZ SALMERÓN, Manuel (Coords). Régimen jurídico de la transparencia del sector público: del Derecho de acceso a la reutilización de información. Navarra: Thomson Reuters, 2014, p. 491.

26 MARTíN DELGADO, Isaac. La configuración legal de las autoridades de transparencia. In: MARTíN DELGADO, Isaac; GUICHOT REINA, Emilio; CERRILLO MARTíNEZ, Agustí. Configuración legal, actuación y funciones de las autoridades de transparencia. Algunas propuestas de mejora. Barcelona-Madrid: Fundación Democracia y Gobierno Local, 2019, p. 23.

$27 \quad$ La adscripción al parlamento autonómico es la fórmula seguida recientemente en la configuración del CTM que está orgánicamente adscrito a la Asamblea de Madrid, del Comisionado de Transparencia y Acceso a la Información Pública de Canarias (CTCn) que depende del Parlamento de esta comunidad autónoma y del Consejo Regional de Transparencia y Buen Gobierno de Castilla-La Mancha (CRTCM) como órgano adscrito a las correspondientes Cortes.

28 MIR PUIGPELAT, Oriol. Las autoridades autonómicas de garantía del derecho de acceso: una aproximación crítica a su diseño institucional. In: TRONCOSO REIGADA, Antonio (Dir.) Comentario a la Ley de Transparencia, Acceso a la Información Pública y Buen Gobierno. Madrid: Civitas, 2017, p. 1828.
} 
considera la adscripción del CTBG como una cuestión meramente "formal" de la que no derivaría una incidencia negativa en su independencia efectiva, la cual quedaría garantizada por su configuración jurídica ${ }^{29}$.

En Andalucía, la Ley 1/2014, de 24 de junio, de Transparencia Pública de Andalucía (LTAn), ha instituido también el Consejo de Transparencia y Protección de Datos de Andalucía (CTPDAn) como autoridad administrativa independiente que pertenece a la Administración Institucional de la Junta de Andalucía; el Consejo está dotado de personalidad jurídica propia y plena capacidad y autonomía orgánica y funcional (art. 43.2 $\mathrm{LTAn}^{30}{ }^{30}$ y se rige por su normativa específica y supletoriamente por lo establecido con carácter general en la ley de régimen jurídico de la administración andaluza. A ello cabe añadir que al CTPDAn se le dota de una competencia adicional de especial importancia, la protección de datos de carácter personal, una solución también presente en algunos ejemplos de derecho comparado ${ }^{31}$. Desde un punto de vista institucional, cabe mencionar que la relación entre el CTPDAn y "la Administración de la Junta de Andalucía se llevará a cabo a través de la Consejería de la Presidencia" (art. 43.4 LTAn). En el siguiente apartado comprobaremos que en la mayoría de la normativa autonómica, los órganos que actúan como autoridades de transparencia canalizan su relación con la administración a la que están adscritas a través de las consejerías competentes en materia de transparencia, en el caso de la autoridad de transparencia balear, aunque la autoridad de transparencia esté adscrita a la Consejería de Presidencia, ésta tiene la competencia en dicha materia.

El Consejo de Transparencia de la Región de Murcia (CTMu) se instituye por el art. 38 de la Ley 12/2014, de 16 de diciembre, de Transparencia y Participación Ciudadana de Murcia (LTMu) como órgano independiente de control. Sin embargo, la norma continúa diciendo que el CTMu se configura como un ente de los previstos en la disposición adicional quinta de la Ley $7 / 2004$, de 28 de diciembre, de Organización y Régimen Jurídico de la Administración Pública de la Comunidad Autónoma de la Región de Murcia, es decir el Consejo Jurídico y el Consejo Económico y Social de la Región

29 SENDÍN GARCÍA, Miguel Ángel. El Consejo de transparencia y buen gobierno. Revista Jurídica de Castilla y León, Valladolid, n. 33, p. 8-9, mai. 2014.

30 Concretamente, el CTAn forma parte, según el art. 44.2 LTAn, de las entidades con régimen de independencia funcional o de especial autonomía, reguladas en la Disposición Adicional 2a de la Ley 9/2007, de 22 de octubre, de la Administración de la Junta de Andalucía, que a efectos prácticos disponen de un régimen jurídico de autonomía muy similar a las autoridades administrativas independientes estatales.

31 En la doctrina, Jiménez Asensio ha puesto de relieve, que el uso de esta fórmula de fusión institucional, presenta algunos inconvenientes derivados de la confusión de los contornos de los derechos de acceso y a la transparencia por su cohabitación en la misma entidad que tiene encomendada la protección de los datos personales; vid. JIMÉNEZ ASENSIO, Rafael. Instituciones de garantía de la transparencia. El Cronista Del Estado Social y Democrático de Derecho, Madrid, n. 68, p. 69-70, 2017. 
de Murcia, dotados de régimen jurídico propio ${ }^{32}$. Luego, el apartado tercero del mismo art. 38 especifica que "[s]u relación con la Administración autonómica se lleva a cabo a través de la consejería competente en materia de transparencia". Por lo tanto, también en el caso de Murcia nos encontramos ante una entidad que deberíamos incluir entre las autoridades administrativas independiente con personalidad diferenciada, si entendemos correctamente el uso de termino "ente" que hace el legislador murciano.

Es preciso considerar, también, que hay dos Comunidades Autónomas que tienen prevista la creación de autoridades independientes dotadas de personalidad jurídica propia, son el Principado de Asturias y el Cantabria. En el Principado de Asturias, la Ley 8/2018, de 14 de septiembre, de Transparencia, Buen Gobierno y Grupos de Interés prevé en el art. 63 que debe crearse el Consejo de Transparencia y Buen Gobierno (CTAs) como ente público con personalidad jurídica propia. Por otro lado, el art. 33 de la Ley 1/2018, de 21 de marzo, de Transparencia de la Actividad Pública de Cantabria (LTCb) afirma por su parte que "[u]na Ley de Cantabria creará el Consejo de Transparencia de Cantabria como órgano con personalidad jurídica propia y plena capacidad de obrar. Actuará con autonomía y plena independencia en el cumplimiento de sus fines". Sin embargo dichas autoridades independientes no han sido aún instituidas hasta la fecha y las reclamaciones en materia de acceso se resuelven por el CTBG estatal con el que se han suscritos sendos convenios de colaboración.

\subsection{Autoridades de Transparencia como órganos adscritos a la Admi- nistración o al Parlamento autonómico}

La mayoría de las Leyes autonómicas aprobadas en la materia que nos ocupa ha configurado sus respectivas autoridades de control de la transparencia como órganos administrativos, por lo tanto sin atribuirles personalidad jurídica propia ni configurarlos como autoridad administrativa independiente. Aunque desde un punto de vista teórico no parece la fórmula más acertada, debe recordarse que la normativa básica estatal otorga a las Comunidades Autónomas un amplio margen para determinar sus autoridades de trasparencia. No obstante, como muy acertadamente se ha resaltado en la doctrina, "tal libertad de configuración no impide encontrar en la normativa estatal algunos criterios de obligado cumplimiento"33. Asimismo, dichos criterios no suponen que la configuración de la autoridad de transparencia deba desembocar en una

\footnotetext{
32 El Art. 38.1 LTMu remite a la Disposición Adicional Quinta de la Ley 7/2004, de 28 de diciembre, de organización y régimen jurídico de la Administración Pública de la Comunidad Autónoma de la Región de Murcia.

33 MARTÍN DELGADO, Isaac. La configuración legal de las autoridades de transparencia. In: MARTÍN DELGADO, Isaac; GUICHOT REINA, Emilio; CERRILLO MARTÍNEZ, Agustí. Configuración legal, actuación y funciones de las autoridades de transparencia. Algunas propuestas de mejora. Barcelona-Madrid: Fundación Democracia y Gobierno Local, 2019, p. 25.
} 
autoridad administrativa independiente en sentido jurídico estricto ${ }^{34}$. A mayor abundamiento, ha sido señalado que, a pesar de que en España el periodo en el que se han instituido las autoridades de transparencia se ha caracterizado por ser una etapa de contención del gasto público, la creación de nuevos órganos administrativos debe valorarse positivamente y considerarse un indicio significativo de compromiso político de las administraciones autonómicas "con el imperativo democrático de garantizar a todos los ciudadanos la transparencia, el acceso a la información pública y el buen gobierno"35. Esperemos, por lo tanto, que la falta de éxito de la fórmula de la atribución autonómica de la competencia para la resolución de las conflictos en materia de acceso a favor del CTBG estatal mediante convenio entre las administraciones (Disposición adicional cuarta, apartado 2, LTBG) responda al mencionado compromiso y active una competencia virtuosa que catalice cada vez mayores niveles de transparencia para la ciudadanía y no sea, en cambio, una réplica del "café para todos" en el terreno de la "administración de la transparencia" y/o aún peor, para que cada Comunidad conozca de "sus propias transparencias" para resguardarlas de miradas ajenas. Para prevenir los riesgos que plantea esta última cuestión, como veremos, es esencial la composición imparcial, profesional y especializada de las autoridades autonómicas de transparencia.

Un ejemplo de autoridad colegiada adscrita en la administración autonómica es la Comisión de Garantía de Acceso a la Información Pública de Cataluña (CGAIP) regulada por los arts. 39, 40 y 41 de la Ley 19/2014, de 29 de diciembre, de Transparencia, Acceso a la Pública y Buen Gobierno de Cataluña (LTCat). Según su Reglamento ${ }^{36}$, la CGDAIP está adscrita al Departamento de la Generalitat competente en materia de políticas de transparencia. Dicho departamento "debe ofrecer la información y el apoyo necesario para garantizar el cumplimiento de la normativa presupuestaria, de personal, patrimonial, de contratación y análogas por parte de la Comisión". La LTCat garantiza que "La Comisión debe cumplir sus funciones con plena independencia orgánica y funcional, sin sumisión a instrucciones jerárquicas de ningún tipo" (art. 39.2 LTCat). No obstante, al tratarse de un órgano de la administración de la Generalitat de Cataluña, no sorprende que su Gobierno haya aprobado el mencionado Reglamento por el que se establece la organización y el funcionamiento de la CGDAIP. Este aspecto, que podría ser un punto negativo en el terreno de la independencia de la autoridad catalana de transparencia ha sido objeto, sin embargo, de una interesante "norma de prevención" por parte del legislador autonómico. En efecto, el art. 41.2 LTCat afirma que el Gobierno

34 VELASCO RICO, Clara. Reconocimiento y protección del derecho de acceso a los documentos público en Quebec: especial referencia a la Comisión de Acceso a la Información. Revista Catalana de Dret Públic, Valladolid, n. 50, p. 136, mai. 2015.

35 BERNARDÍ GIL, Xavier. Una visión general de la Llei 19/2014, del 29 de desembre, de transparència, accés a la informació pública i bon govern. Activitat Parlamentària, Barcelona, n. 28, p. 63, mai. 2015.

36 Art. 4 del Decreto 111/2017, de 18 de julio, por el que se aprueba el Reglamento de la Comisión de Garantía del Derecho de Acceso a la Información Pública (RCGAIP). 
debe remitir al Parlamento el proyecto de reglamento antes de su aprobación como decreto y que el "Parlamento debe pronunciarse sobre la propuesta presentada por el Gobierno y, en su caso, puede formular recomendaciones con relación al texto", especificando que "[l]as recomendaciones relativas a la garantía de la independencia orgánica y funcional de la Comisión son vinculantes para el Gobierno". Se trata de una previsión insólita e interesante que tiene como finalidad reforzar el estatuto de independencia y autonomía de la CGDAIP mediante la fórmula de aprobación de la norma que regula su actuación ${ }^{37}$. En la doctrina se han levantado voces reclamando que "[e]l esquema que podría haber cerrado un diseño más coherente conllevaría que la provisión de medios, la aprobación de su reglamento y su propia dependencia fuese del Parlamento"38. Sin embargo, se ha entendido que haber optado por la formula del órgano adscrito a la administración de la Generalitat lo conectaría con la potestad de autoorganizativa de la propia administración, sin que ello deba necesariamente comprometer a priori la potencialidad de la CGDAIP ${ }^{39}$. A tal propósito, no debe confundirse la CGDAIP ${ }^{40}$ con la Comisión Interdepartamental de Transparencia y Gobierno Abierto de Cataluña, que es un Comisión integrada por las personas titulares de varios órganos de la administración catalana con el fin de aprobar y evaluar estrategias y directrices para garantizar el cumplimiento de la normativa de transparencia y gobierno abierto, hacer el seguimiento del Plan de Gobierno Abierto, proponer normativa de desarrollo, aprobar buenas prácticas en materia de transparencia y buen gobierno ${ }^{41}$. Esta diferencia sustancial nos hace discrepar con la crítica según la cual en el sistema catalán se ha dado lugar a una multiplicación de órganos con competencias que se solapan entre sít2.

La grupo más numeroso de autoridades autonómicas de transparencia pertenece a la presente categoría en la cual el órgano de transparencia - proclamado siempre

37 CAPDEVILA PONCE, Gemma; SOLERNOU VIÑOLAS, Àgata. El sistema de garanties previsto en la Lei de transparència, accés a la informació i bon govern. Activitat Parlamentària, Barcelona, n. 28, p. 95, 2015.

38 SIERRA RODRÍGUEZ, Javier. Una crítica al diseño de los organismos de garantía del derecho de acceso en las comunidades autónomas. Revista Jurídica de Castilla y León, Valladolid, n. 45, p. 100, mai. 2018.

39 SIERRA RODRÍGUEZ, Javier. Una crítica al diseño de los organismos de garantía del derecho de acceso en las comunidades autónomas. Revista Jurídica de Castilla y León, Valladolid, n. 45, p. 100, mai. 2018.

40 La función función principal de la CGDAIP es cuasi judicial, y por ende dotada especial autonomía e independencia, es la de resolver las reclamaciones contra las resoluciones expresas o presuntas y las comunicaciones que sustituyan las resoluciones en materia de acceso a la información pública y la de mediar en los conflictos entre las personas y la Administración de la Generalitat y su sector público relacionados con el derecho de acceso a la información pública (art. 7.2 del Decreto 111/2017, por el que se aprueba el reglamento de la CGAIP). Sobre las otras funciones de la CGDAIP y de las otras autoridades de Transparencia: CERRILLO MARTÍNEZ, Agustí. Configuración legal, actuación y funciones de las autoridades de transparencia. Algunas propuestas de mejora. Barcelona-Madrid: Fundación Democracia y Gobierno Local, 2019, p. 125-173.

41 Decreto 233/2016, de 22 de marzo, por el que se crea la Comisión Interdepartamental de Transparencia y Gobierno Abierto.

42 INSTITUTO NACIONAL DE ADMINISTRACIÓN PÚBLICA (INAP). La normativa autonómica en materia de derecho de acceso a la información pública. Madrid: Instituto Nacional de Administración Pública (INAP), 2016, p. 187. 
independiente por su correspondiente ley de creación - está adscrito a o se relaciona con la consejería o departamento autonómico responsable en materia de transparencia (las formulas empleadas varían en cada caso y son propias y características casi de cada ley). La totalidad de las autoridades se rigen por sus normas específicas, y supletoriamente por las normativas autonómicas. En el caso del Consejo de Transparencia de Aragón (CTAr), el art. 37 de la Ley 8/2015, de 25 de marzo, de Transparencia de la Actividad Pública y Participación Ciudadana de Aragón (LTAr) establece que el Consejo actuará con independencia orgánica y funcional pero estará adscrito al departamento responsable en materia de transparencia que pondrá a disposición del CTAr los medios y recursos necesarios para el ejercicio de sus funciones; esta última circunstancia puede potencialmente incidir negativamente en la actividad del Consejo que podría verse infradotado de los recursos necesarios para hacer frente a sus cometidos institucionales. Obsérvese que el Decreto por el que se aprueba el Reglamento del CTAr establece que "[l]a creación y puesta en funcionamiento del Consejo de Transparencia de Aragón no podrá⿴囗 suponer incremento de dotaciones, retribuciones u otros gastos de personal ni, por otros conceptos, incremento neto de estructura o de personal al servicio de la Administración de la Comunidad Autónoma de Aragón"433. Suerte parecida tiene el Consejo de Transparencia, Acceso a la Información Pública y Buen Gobierno de la Comunidad Valenciana (CTCV), que de acuerdo con la Ley 2/2015, de 2 de abril, de Transparencia, Buen Gobierno y Participación Ciudadana (LTCV), actuará con plena independencia funcional para el cumplimiento de sus fines y recibirá "soporte administrativo [...] por una unidad administrativa de la consejería competente en materia de transparencia y acceso a la información pública" (Art. 39 LTCV). Su desarrollo reglamentario especifica que se trata de adscripción al departamento competente en materia de transparencia, aunque se aclara que el CTCV estará dotado de medios económicos y materiales suficientes y un programa presupuestario propio ${ }^{44}$.

A la formula de la integración en el departamento en materia de transparencia y atención ciudadana recurre también el Decreto 128/2016, de 13 de septiembre, de la Comisión Vasca de Acceso a la Información Pública (CVAIP) que tiene naturaleza de "órgano colegiado de carácter independiente" (art. 1). No se aparta, en el fondo, de la regla de la adscripción a la consejería o departamento competente en materia de transparencia la recientemente instituida Comisión para las Reclamaciones de Acceso a la Información Pública de las Islas Baleares (CRAIPIB). En efecto, el art. 1.4 del Decreto 1/2019, de 11 de enero, regulador de CRAIPIB afirma que "[I]a Comisión se adscribe, a

43 Decreto 32/2016, de 22 de marzo, del Gobierno de Aragón, por el que se aprueba el Reglamento de Organización y de Funcionamiento del Consejo de Transparencia de Aragón.

44 Arts. 73-78 del Decreto 105/2017, de 28 de julio, del Consell, de desarrollo de la Ley 2/2015, de 2 de abril, de la Generalitat, en materia de transparencia y de regulación del Consejo de Transparencia, Acceso a la Información Pública y Buen Gobierno. 
efectos del apoyo administrativo y sin dependencia jerárquica, a la Consejería de Presidencia, como competente en materia de transparencia y buen gobierno". La Ley Foral 5/2018, de 17 de mayo, de Transparencia, Acceso a la Información Pública y Buen Gobierno (LTNv), determina que el Consejo de Transparencia de Navarra (CTNv), "como órgano independiente destinado a promover la trasparencia en al Comunidad Foral" (art. 63.1), "se adscribirá orgánicamente al Departamento de Presidencia, Función Pública, Interior y Justicia y, en el ejercicio de las funciones que la presente ley foral le atribuye, actuará con objetividad, profesionalidad, sometimiento al ordenamiento jurídico, autonomía y plena independencia (art.63.2).

Por último, quedan por mencionar, dentro del presente grupo de autoridades sin personalidad jurídica diferenciada, un subgrupo de órganos que en lugar de quedar adscriptos a los ejecutivos autonómicos, dependen de las cámaras legislativas. Esta fórmula resulta de gran interés en la medida en que, al menos desde una perspectiva formal, supone alejar las autoridades de control de la administración sobre cuyas resoluciones tendrán que pronunciarse. Tres son las autoridades autonómicas de transparencia que tiene adscripción o dependencia orgánica de sus respectivos parlamentos: se trata de los casos de Canarias, Castilla-la Mancha y Madrid.

El Comisionado de Transparencia y Acceso a la Información Pública de Canarias (CTCn), instituido por la Ley 12/2014, de 26 de diciembre, de transparencia y de acceso a la información pública de Canarias (LTCn), es un órgano unipersonal que actúa con autonomía y plena independencia para el "fomento, análisis, control y protección de la transparencia pública y del derecho de acceso a la información pública en el ámbito de la Comunidad Autónoma" (art. 58 LTCn). El art. 62 de la ley canaria establece que "[l] a organización y funcionamiento del comisionado o comisionada de Transparencia y Acceso a la Información Pública se regirá por el reglamento aprobado por la Mesa del Parlamento, a propuesta del mismo" añadiendo que "[p]ara el ejercicio de las funciones de transparencia y acceso a la información pública, el comisionado o comisionada de Transparencia y Acceso a la Información Pública contará con el apoyo jurídico, técnico y administrativo del Parlamento de Canarias, así como con los medios personales y materiales del mismo que sean necesarios". Debe ser destacado, con el nuevo Estatuto de Autonomía de Canarias, ratificado por el Senado el 24 de octubre de 2018, el CTCn ha sido recogido en el art. 60 del Estatuto convirtiéndose en el primer órgano de control de la transparencia español de carácter estatutario y reconocido en el bloque de constitucionalidad. También el Consejo Regional de Transparencia y Buen Gobierno de Castilla-La Mancha (CRTCM) es un órgano adscrito a las Cortes de dicha Comunidad Autónoma, regulado por el Capítulo II (arts. 61-66) de la Ley 4/2016, de 15 de diciembre, de Transparencia y Buen Gobierno de Castilla-La Mancha (LTCM). Como ya se ha dicho anteriormente, la reciente Ley 10/2019, de 10 de abril, de Transparencia y de Participación de la Comunidad de Madrid determina que el CTM está orgánicamente adscrito 
a la Asamblea de Madrid y que "[p]ara el ejercicio de las funciones en materia de transparencia y participación, contará con una unidad de apoyo jurídico, técnico, y administrativo de la Asamblea de Madrid, así冈 como de los medios personales y materiales que sean necesarios".

\subsection{Autoridades de transparencia vinculadas a los Defensores del Pueblo}

La tercera casuística incluye dos Comunidades Autónomas: Galicia y Castilla y León, y se caracteriza por autoridades de transparencia que desarrollan sus funciones mediante los Defensores del Pueblo. El diseño institucional de dichas autoridades es parecido pero, como ha observado la doctrina, resulta cualitativamente distinto ${ }^{45}$, por ello merece una serie de consideraciones que desarrollaremos a continuación.

La Ley 1/2016, de 18 de enero, de transparencia y buen gobierno de Galicia (LTGa), en el Capítulo V, dedicado a los mecanismos de coordinación y control, crea dos órganos: el Comisionado de Transparencia (CTVP) y la Comisión de Transparencia (CT$\mathrm{Ga})^{46}$. Las funciones del Comisionado (art. 32), como órgano independiente de control del cumplimiento de las obligaciones establecidas por la LTGa son numerosas y abarcan responder con carácter facultativo determinadas consultas, adoptar recomendaciones para el mejor cumplimiento de la LTGa, emitir informes sobre proyectos normativos cuando afectan cuestiones de transparencia y buen gobierno, efectuar requerimientos para la subsanación de los incumplimientos derivados de las obligaciones en materia de publicidad activa, etc. La Ley, en el primer apartado del mismo art. 32, atribuye dichas funciones del Comisionado de Transparencia al Valedor del Pueblo (el Defensor del Pueblo en Galicia). Sin embargo, la competencia para resolver las reclamaciones frente a las resoluciones de acceso a la información pública se asigna a un órgano colegiado que crea la misma LTGa en el art. 33 y que se denomina Comisión de Transparencia (CTGa). Dicha Comisión estará adscrita al Valedor del Pueblo que presidirá el órgano colegiado integrado, además, por una vicepresidencia que corresponde al adjunto del Valedor, y otros cuatro vocales de procedencia muy distinta (la Administración Autonómica, el Consejo Consultivo, el Consejo de Cuentas y la Federación gallega de municipios y provincias), ostentando el Presidente el voto dirimente en caso de empate.

El modelo castellanoleonés es muy parecido: la Ley 372015, de 4 de marzo, de Transparencia y Participación Ciudadana de Castilla y León (LTCL, art. 11-15), crea el Comisionado de Transparencia (CTPC), cuyas funciones son, esencialmente, las de evaluar

45 SIERRA RODRÍGUEZ, Javier. Una crítica al diseño de los organismos de garantía del derecho de acceso en las comunidades autónomas. Revista Jurídica de Castilla y León, Valladolid, n. 45, p. 103, mai. 2018.

46 OTERO PARGA, Milagros María. Transparencia e información publica. Revista Española de la Transparencia, Madrid, n. 4, p. 66-86, sep. 2017. 
el grado de cumplimiento de la LTCL, velar por el cumplimiento de la publicidad activa y responder facultativamente a las consultas que les planteen los órganos encargados de tramitar y resolver solicitudes de acceso. De la misma manera que en Galicia, las funciones del CTPC se atribuyen al Procurador del Común (el Defensor del Pueblo en Castilla y León), a la vez que se instituye una Comisión de Transparencia (CTCL), como órgano colegiado adscrito al Procurador del Común. Sin embargo, la composición de la CTCL es distinta de su homóloga gallega. En efecto, se compone de tres miembros: el propio Procurador del Común que la presidirá; el adjunto del Procurador, si existe, u otra persona designada de la misma institución; y un secretario, siempre designado por el Procurador del Común y perteneciente a la misma institución.

Como ha sido oportunamente observado ${ }^{47}$, la similitud entre los dos diseños institucionales descritos no esconde la clara posición de prevalencia e influencia que ostenta el Procurador del Común respecto al Valedor del Pueblo debido a la composición orgánica de la correspondiente Comisión de Transparencia.

Lo que es interesante destacar es que la solución institucional presentada en este modelo permite cumplir con el requisito del carácter colegiado del órgano que tenga que resolver las reclamaciones sustitutivas del régimen ordinario de recursos administrativos previsto en el art. 112 LPAC $^{48}$ (cuestión que se abordará en el siguiente epígrafe).

Por otra parte, deben señalarse las críticas dirigidas a este modelo de autoridad que se apoya en los Defensores del Pueblo que se considera inadecuado para el desarrollo de funciones de control en materia de transparencia y garantía del derecho de acceso, por carecer las actuaciones de estas instituciones de carácter coercitivo ${ }^{49}$. Si bien es cierto, debe igualmente decirse que se trata de una cuestión que afecta y es extensible a la mayoría de autoridades de transparencias, cuyas normas reguladoras normalmente no les otorgan potestades de ejecución forzosa de sus resoluciones ni potestades sancionadoras en los supuestos más graves de incumplimiento. Dichas circunstancias inciden muy negativamente en la eficacia de las actuaciones de las autoridades de transparencia ${ }^{50}$. Excepciones son el CTNv y el CTAr, cuya normativa reguladora les otorga la potestad de imponer multas coercitivas.

\footnotetext{
47 SIERRA RODRÍGUEZ, Javier. Una crítica al diseño de los organismos de garantía del derecho de acceso en las comunidades autónomas. Revista Jurídica de Castilla y León, Valladolid, n. 45, p. 103, mai. 2018.

48 MARTÍN DELGADO, Isaac. La configuración legal de los consejos autonómicos de transparencia: algunos riesgos para el ejercicio de su función de control. Dilemata, Madrid, n. 27, p. 32, abr. 2018.

49 OTERO PARGA, Milagros María. El compromiso con la transparencia: Especial referencia a la realidad gallega. Derechos y Libertades: Revista del Instituto Bartolomé de las Casas, Madrid, n. 39, p. 308-309, jun. 2018.

50 MARTÍN DELGADO, Isaac. La reclamación ante el Consejo de Transparencia y Buen Gobierno: un instrumento necesario, útil y ¿eficaz? In: LÓPEZ RAMÓN, Fernando (Coord.). Las vías administrativas de recurso a debate. Madrid: INAP, 2016, p. 291-328. MARTíN DELGADO, Isaac. La configuración legal de los consejos
} 


\section{COMPOSICIÓN DE LAS AUTORIDADES DE TRANSPARENCIA Y ESTATUTO DE LOS MIEMBROS DE SUS ÓRGANOS RECTORES}

\subsection{Carácter unipersonal o colegiado y su relevancia}

Anteriormente se ha observado que la LTBG ha otorgado un amplio margen a las Comunidades Autónomas para determinar la estructura de sus propias autoridades de transparencia; en efecto, la ley estatal ha prescindido de establecer requisitos mínimos formales inherentes a la composición, nombramiento, mandato y estatuto de sus miembros, además de la indeterminación de la naturaleza jurídica que se ha tratado anteriormente. Sin embargo, tal como se ha comentado por parte de la doctrina más atenta, la parquedad normativa de la LTBG no implica que no se puedan deducir, de una lectura sistemática del marco normativo, una serie de requisitos exigibles para que una autoridad autonómica pueda configurarse "como un auténtico órgano de control operativo y eficaz"51 (Martín Delgado, I., 2019, p. 25). Así, siguiendo a Martín Delgado, debe observarse lo siguiente:

El art. 23 de la LTBG ha establecido que la reclamación (potestativa y previa a la impugnación en vía contencioso-administrativa) ante el CTBG "tendrá la consideración de sustitutiva de los recursos administrativos" ordinarios. Y que dicha reclamación ante una autoridad independiente en materia de transparencia tiene una función de control de la legalidad de las resoluciones dictadas en el ámbito del ejercicio del derecho de acceso a la información pública.

La remisión del art. 23 LTBG al antiguo 107.2 LRJPAC debe entenderse al vigente art. 112 de la Ley 39/2015, de 1 de octubre, del Procedimiento Administrativo Común de las Administraciones Públicas (LPAC) ${ }^{52}$. Es fundamental, llegados a este punto, recordar que el apartado 2 del art. 112 LPAC es preclaro en afirmar que: "Las leyes podrán sustituir el recurso de alzada, en supuestos o ámbitos sectoriales determinados, y cuando la especificidad de la materia así lo justifique, por otros procedimientos de impugnación, reclamación, conciliación, mediación y arbitraje, ante órganos colegiados o Comisiones específicas no sometidas a instrucciones jerárquicas, con respeto a los principios, garantías y plazos que la presente Ley reconoce a las personas y a los interesados en todo procedimiento administrativo".

autonómicos de transparencia: algunos riesgos para el ejercicio de su función de control. Dilemata, Madrid, n. 27, p. 39, abr. 2018.

51 MARTÍN DELGADO, Isaac. La configuración legal de los consejos autonómicos de transparencia: algunos riesgos para el ejercicio de su función de control. Dilemata, Madrid, n. 27, p. 25, abr. 2018.

52 El art. 23 de la LTBG remitía al art. 107.2 de la Ley 30/1992, de 26 de noviembre, de Régimen Jurídico de las Administraciones Públicas y del Procedimiento Administrativo Común (LRJPAC) que ha sido derogada por la Ley 39/2015, de 1 de octubre, del Procedimiento Administrativo Común de las Administraciones Públicas (LPAC). 
La ya mencionada Disposición Adicional Cuarta de la LTBG establece que en el caso de resoluciones dictadas por órganos de las Administraciones autonómicas, su sector público y las entidades locales de su ámbito territorial, la resolución de la reclamación prevista en el art. 24 de la LTBG, corresponderá al órgano independiente que determina la Comunidad Autónoma.

Como conclusión de lo expuesto, se puede inferir que a la hora de configurar normativamente una autoridad de transparencia, que tenga encomendada la función de conocer de un medio alternativo de impugnación, tal como la reclamación en materia de transparencia, el legislador autonómico se encuentra ante tres requisitos a cumplir: independencia, especialización y carácter colegiado. Obsérvese que este último requisito, que como hemos visto deriva de la LPAC, resultaría aplicable al órgano que tenga la competencia para resolver las reclamaciones, a pesar de que la LTBG no lo requiera. En este sentido, afirma Martín Delgado que el órgano autonómico deberá reunir los tres citados requisitos “[y] deberá hacerlo como condiciones de constitucionalidad puesto que han sido incorporadas en normativa reguladora del procedimiento administrativo común y a través de la LTBG, en normativa básica estatal" 53 .

A la luz de lo que se acaba de exponer, en España hay cuatro autoridades de transparencia que incumplen el requisito de colegialidad exigido por el art. 112 LPAC (que requiere que las reclamaciones sustitutivas de los recursos deban ser conocidas por órganos colegiados o comisiones específicas). En concreto:

El CTBG estatal en el que - a pesar de ser una autoridad independiente, con personalidad diferencia y diseñada como órgano colegiado (y no obstante el art. 24.6 LTBG diga que "La competencia para conocer de dichas reclamaciones corresponderá al Consejo de Transparencia y Buen Gobierno") - será su Presidente quien tiene la función de "[c]onocer de las reclamaciones que se presenten en aplicación del artículo 24 de esta Ley", tal como establece el art. 38.2.c).

En Andalucía ocurre lo mismo. El CTPDAn como autoridad administrativa independiente, se articula en una Comisión Consultiva y en un órgano unipersonal de Dirección, cuyo titular además de ostentar la presidencia de la Comisión (art. 46 LTAn), tendrá la competencia para resolver las reclamaciones en materia de transparencia (art. 48.1.b LTAn).

En Asturias, donde el CTAs está previsto por ley autonómica de trasparencia pero aún no ha sido puesto en marcha, sin embargo a pesar de tener que constituirse como ente público dotado de personalidad jurídica propia y disponer del un pleno (art. 64 LTAs), su normativa reguladora atribuye al Presidente la competencia de conocer de las reclamaciones sustitutivas de los recursos administrativos ordinarios (art. 66 LTAs).

53 MARTÍN DELGADO, Isaac. La configuración legal de los consejos autonómicos de transparencia: algunos riesgos para el ejercicio de su función de control. Dilemata, Madrid, n. 27, p. 27, abr. 2018. 
Por último, en el caso canario, el Comisionado de Transparencia es órgano unipersonal adscrito al Parlamento de Canarias (art. 62 LTCn).

Hemos destacado ya la interesante solución adoptada en Galicia y en Castilla y León, donde las funciones de los Comisionados de Trasparencia se atribuyen a los respectivos defensores del pueblo, pero se asigna a las Comisiones de Transparencia (arts. 33.3 LTGa y 13.3 LTCL), como órganos colegiados independientes presididos por los correspondientes Defensores del Pueblo, la resolución de las reclamaciones frente a las resoluciones de acceso a la información pública.

En los demás casos, los órganos autonómicos competentes para conocer de las reclamaciones son entes u órganos de naturaleza colegiada. Las ventajas de esta configuración son notorias y atañen a la necesidad del debate para deliberar, lo que implica tener en cuenta una multiplicidad de consideraciones y perspectivas que proceden de los miembros que integran el órgano, si bien es cierto que "la colegialidad en sí misma no es garantía absoluta de imparcialidad, pues esta dependerá de la composición del órgano, de la forma en la que sean elegidos sus miembros y del modo concreto de ejercer su función. Sin embargo el precepto es claro [112 LPAC] a la hora de exigir que el órgano a que se encomiende la resolución de los medios de impugnación alternativos haya de ser de carácter colegiado" ${ }^{54}$.

Ahora bien, más allá de la cuestión derivada del requisito previsto en la LPAC, respecto del órgano competente para resolver la reclamaciones, otras reflexiones pueden ser desarrolladas sobre el diseño de las autoridades de transparencia. Es posible entrar a valorar aquellas autoridades en las cuales el Presidente o Director tiene un papel destacado que imprime en la autoridad un cierto carácter presidencialista, respecto de otras autoridades que presentan un funcionamiento más colegiado. Nos adentramos, pues, a considerar el margen del que disponen los legisladores autonómicos para configurar (libremente) sus autoridades (colegiadas). Se puede incluir, entre las autoridades cuyo presidente tiene una primacía destacada, el CTBG nacional, consideradas las funciones ejecutivas y de relevancia sustancial de la presidencia de dicha entidad ${ }^{55}$. EI CTPDAn de Andalucía se caracteriza por una distribución de poderes muy similar. La primacía, in re ipsa, resulta en los dos modelos vinculados a los Defensores del Pueblo y, muy señaladamente, en el caso específico del Procurador del Común castellanoleonés.

Por otra parte, un segundo grupo de autoridades de trasparencia presenta un marcado carácter colegiado. Si bien la normativa autonómica regule el órgano de presidencia, a diferencia de los ejemplos anteriores, la presidencia asume fundamentalmente

\footnotetext{
54 MARTÍN DELGADO, Isaac. La configuración legal de los consejos autonómicos de transparencia: algunos riesgos para el ejercicio de su función de control. Dilemata, Madrid, n. 27, p. 33, abr. 2018.

55 Arts. 38.2 LTBG y 8.2 de su estatuto. Por el contrario, las facultades otorgadas a la Comisión -el órgano colegiado integrado por el resto de miembros del CTBG- son esencialmente consultivas (arts. 38.1 LTBG y 12 del estatuto)
} 
funciones de representación de la autoridad, de convocatoria de sesiones, o dirección del personal, sin reunir el núcleo esencial de las facultades de dirección, que siguen residiendo en el conjunto del Consejo. Un ejemplo de este diseño institucional es el caso navarro de la CTNv (art.65 LTNv). Aún más destacado es el carácter colegiado del CTAr aragonés, cuyo presidente es escogido entre sus miembros por el propio Consejo (art. 7 RCTAr). Lo mismo ocurre con la CGDAIP catalana ${ }^{56}$, el CTCV valenciano ${ }^{57}$ y la CRAIPIB de las islas Baleares ${ }^{58}$ o en la Comunidad de Madrid, donde la presidencia del CTM será rotatoria entre los tres miembros del Consejo, aunque la Asamblea de Madrid, además de elegir lo miembros del Consejo, determinará el orden en que accederán a la presidencia del mismo.

Las consideraciones realizadas sobre el diseño institucional, que espacia entre el "más colegiado" y el "más presidencialista", son muy variadas. Algunos autores expresan una opinión crítica respecto del modelo en el que sobresale la figura del Presidente de la autoridad, sobre la base del argumento que dicha configuración se alejaría de la lógica propia de una autoridad independiente, al dejar una parte muy importante del funcionamiento del órgano en las manos de su presidente, y por ende, exponiéndolo a posibles presiones ${ }^{59}$. No obstante, Jiménez Asensio considera que en los supuestos en los cuales se produce una elección por las cámaras legislativas o el refrendo del nombramiento por parte de una Comisión parlamentaria (como en el caso del Presidente del CTBG), su carácter unipersonal reduce la tendencia al "sistema de cuotas" entre partidos y favorece la designación de perfiles ideológica y políticamente más neutrales e independientes ${ }^{60}$. Sin embargo, aunque se haya anotado que la colegialidad puede restar cierta eficiencia al funcionamiento y proceso de toma de decisiones de la autoridades $^{61}$, nos parece que la pluralidad y colegialidad aporten, a priori, mayores ventajas.

\footnotetext{
56 Art. 15.1 del Decreto 111/2017, de 18 de julio, por el que se aprueba el Reglamento de la CGDAIP.

57 Art. 83.1 del Decreto 105/2017, de 28 de julio, del Conseill, de desarrollo de la LTCV.

58 Art. 3.4 del Decreto 1/2019, de 11 de enero, regulador del la CRAIPIB.

59 ORDUÑA PRADA, Enrique, SÁNCHEZ SAUNDINÓS, José Manuel. Comentario al artículo 37. Presidente del Consejo de Transparencia y Buen Gobierno. TRONCOSO REIGADA, Antonio (Dir.) Comentario a la Ley de Transparencia, Acceso a la Información Pública y Buen Gobierno, Madrid: Civitas, 2017, p. 939; SENDíN GARCÍA, Miguel Ángel. El Consejo de transparencia y buen gobierno. Revista Jurídica de Castilla y León, Valladolid, n. 33, p. 13-14, mai. 2014; SIERRA RODRÍGUEZ, Javier. Una crítica al diseño de los organismos de garantía del derecho de acceso en las comunidades autónomas. Revista Jurídica de Castilla y León, Valladolid, n. 45, p. 81-82, mai. 2018.

60 JIMÉNEZ ASENSIO, Rafael. Instituciones de garantía de la transparencia. El Cronista Del Estado Social y Democrático de Derecho, Madrid, n. 68, p. 71, 2017;

61 INSTITUTO NACIONAL DE ADMINISTRACIÓN PÚBLICA (INAP). La normativa autonómica en materia de derecho de acceso a la información pública. Madrid: Instituto Nacional de Administración Pública (INAP), 2016, p. 161
} 


\subsection{Composición de las autoridades de transparencia}

El análisis de las leyes de transparencia, tanto la estatal como las autonómicas, pone de manifiesto que los miembros de las autoridades son elegidos, designados y/o representan colectivos, instancias o formaciones de distinta procedencia que es posible agrupar en cuatro categorías: 1) Representantes de las administraciones y/o de organismos públicos; 2) representantes de grupos parlamentarios; 3) Expertos; 4) Representantes de la sociedad civil. A continuación se identificarán algunos ejemplos concretos. Sin embargo, deben realizarse dos avisos: en primer lugar, remarcar que existe una gran heterogeneidad en la composición de cada organismo y que, dependiendo de cada caso, los representantes de estas categorías puede mezclarse y estar presentes en el consejo de las autoridades; en segundo lugar, que se prestará a continuación especial atención a aquellas autoridades de transparencia que tienen u operan en una conformación colegiada para la resolución de las reclamaciones, condición que, según hemos visto, constituye un requisito exigido por la LPAC. Así por ejemplo, en el caso estatal del CTBG, es el Presidente quién ostenta dicha competencia, mientras la Comisión con funciones de asesoramiento, evaluación e informe se compone tanto de representantes políticos (un diputado y un senador), como de la propia AGE (de la secretaría de Estado de Administraciones Públicas), además de representantes de autoridades independientes (Agencia Española de Protección de Datos y Autoridad Independiente de Responsabilidad Fiscal) y de instituciones de control (Tribunal de Cuentas, Defensor del Pueblo).

Representantes de las administraciones y/o de entes públicos. En el caso de la Región de Murcia, el CTMu se configura como una de las autoridades con una de las composiciones más plurales y diversas. Entre los miembros que proceden de administraciones y entes públicos deben señalarse aquellos que representan las consejerías y órganos competentes en materia de transparencia, hacienda y protección de datos; además se suman representantes de las universidades públicas, del Consejo Jurídico y del Consejo Económico y Social, así como de la federación de Municipios de Murcia (arts. 38.5 LTMu). Otro ejemplo de composición compleja es el CTNv en el que, además del representante del departamento competente en materia de transparencia, se añaden tres representantes de los Entes Locales, uno del Consejo de Navarra, uno de la Cámara de Cuentas, uno de la Universidad Pública de Navarra y otro del Defensor del Pueblo. En el modelo de las autoridades vinculadas a los Defensores del Pueblo, puede señalarse el ejemplo de Galicia, donde su CTGa está integrada por el Valedor del Pueblo, que la preside, su adjunto, y otros cuatro vocales procedentes, respectivamente, de la Comisión Interdepartamental de Información y Evaluación del Gobierno gallego, del Consejo Consultivo y del Consejo de Cuentas, a los que suma también un representante de la Federación Gallega de Municipios y Provincias (art. 33 LTGa). En el segundo caso de autoridad vinculada al Defensor del Pueblo, la CTCL es un órgano integrado por el 
Procurador del Común, un secretario y un vocal procedente de la misma estructura burocrática del Procurador castellanoleonés. Nótese que se han incluido en esta categoría los representantes de las Federaciones de Municipios y Provincias, las cuales, a pesar de ser entidades privadas de base asociativa, no dejan de ser expresión de los intereses de las administraciones territoriales locales que las integran y que pueden ser objeto de reclamaciones de acceso, además de tener deberes de publicad activa.

Representantes de los grupos parlamentarios. Algunas autoridades de transparencia cuentan con la representación de los parlamentos. Si nos centramos en aquellas en las cuales existe un órgano colegiado competente para la resolución de las reclamaciones alternativas al régimen ordinario de los recursos administrativos, debe destacarse el caso del Comunidad Valenciana donde la Comisión Ejecutiva del CTCV, depositaria de la citada competencia, se compone de un número de miembros igual al número de grupos parlamentarios con representación en la cámara legislativa valenciana que elegirá además el presidente de la Comisión. Nótese que en el supuesto de la CTCV no hay participación directa de los parlamentarios, sino que son los grupos políticos que eligen su propio candidato entre personas que deben tener experiencia, competencia y prestigio con al menos diez años de experiencia profesional ${ }^{62}$. A pesar de ello, queda manifiesto que en este modelo si articula un sistema de repartición pro-cuota de base partidista.

Las leyes de transparencia de Aragón, Murcia y Navarra establecen que en sus respectivos consejos de transparencia, entre a varias instancias que los componen, estén los representantes de cada grupo parlamentario de sus asambleas legislativas ${ }^{63}$.

Expertos. En ciertas autoridades de transparencia el diseño institucional resalta el perfil técnico, la trayectoria y los conocimientos profesionales de sus miembros, a pesar de no darse, tampoco en estos casos, ni una suficientemente precisa ni uniforme regulación. Así si tomamos, por ejemplo, el caso del Presidente del CTBG estatal, veremos que debe ser elegido entre personas de "reconocido prestigio y competencia profesional" (arts. 37.1 LTBG y 9.2 del reglamento del CTBG), sin más detalles. La misma indeterminación se manifiesta la leyes autonómicas de Canarias respecto de su Comisionado (art. 59.1), así como de Murcia (art. 38.6) y de Navarra (art. 65.2 LTNv) para los presidentes de sus respectivos consejos de transparencia, siendo en estos tres casos dichos órganos elegidos por los parlamentos autonómicos. La indeterminación de la fórmula empleada en estos supuestos por la normativa ha sido criticada en la medida en que puede transformarse en un mero formulismo del cual no se derivan límites a los potenciales candidatos ${ }^{64}$.

\footnotetext{
62 Arts. 79, 81, 82, 83 del Decreto 105/2017, de 28 de julio, del Consell, de desarrollo de la LTCV.

63 Arts. 38.5.a) LTMu, 37.4.a) LTAr, y 65.1.a) LTNv.

64 JIMÉNEZ ASENSIO, Rafael. Instituciones de garantía de la transparencia. El Cronista Del Estado Social y Democrático de Derecho, Madrid, n. 68, p. 69-73, 2017.
} 
En cambio, otras normativas autonómicas son más precisas e inciden con más concreción en el perfil técnico y en el requerimiento de una trayectoria profesional acreditada para los miembros de las autoridades de transparencia. Por ejemplo, en la Comunidad Valenciana, los miembros del Comisión Ejecutivo del CTCV deben ser expertos "con competencia y prestigio reconocidos y con más de diez años de experiencia profesional"65. En Andalucía, el Director del CTPDAn debe ser designado por el Parlamento andaluz y tratarse de "La designación deberá recaer en una persona de reconocido prestigio y competencia profesional, con una experiencia mínima de quince años en materias relacionadas con la administración pública"66. El modelo fijado en la normativa balear es de lo más adecuado al establecer que los tres miembros de la CRAIPIB deben ser juristas de reconocido prestigio con más de 5 años de experiencia profesional en el ámbito del derecho público ${ }^{67}$. En el caso catalán, la CGAIP está integrada por un mínimo de tres y un máximo de cinco miembros, los cuales deben ser “juristas especialistas en derecho público y técnicos en materia de archivos o gestión documental, elegidos entre expertos de reconocida competencia y prestigio y con más de diez años de experiencia profesional"68. El control sobre el perfil técnico de los candidatos se refuerza por la comparecencia preceptiva de los candidatos ante la comisión parlamentaria correspondiente de la cámara catalana. Desde la doctrina también se ha apuntado a que el alto nivel de requerimientos reduce las posibilidades de que los puestos sean ocupados por personas que respondan más a los intereses de los grupos parlamentarios como formaciones políticas (individualmente o por acuerdo entre ellos), que a la idoneidad en función de las labores a desempeñar ${ }^{69}$. Sin embargo parece acertada la crítica de la doctrina sobre la composición de la CGAIP, ya que dicha Comisión, al tener encomendada una función cuasi-judicial de control de legalidad sobre las reclamaciones en materia de derecho de acceso, debería contar de forma exclusiva con expertos con formación jurídica, siendo cuestionable que a las competencias reservadas a esta autoridad puedan desempeñarse de la forma técnicamente más correcta también por expertos en materia de archivos o gestión documental ${ }^{70}$. En este sentido, el legislador madrileño intenta afinar mayormente en este aspecto estableciendo que los consejeros

\footnotetext{
65 Arts. 41.1 LTCV y 83.2 del decreto 105/2015 de desarrollo de la LTCV.

66 Art. 11.1 del Decreto 434/2015, de 29 de septiembre, por el que se aprueban los Estatutos del Consejo de Transparencia y Protección de Datos de Andalucía.

67 Art. 3.1 del Decreto 1/2019, de 11 de enero, regulador de la Comisión para las Reclamaciones de Acceso a la Información Pública.

68 Art. 40 LTCat.

69 SIERRA RODRÍGUEZ, Javier. Una crítica al diseño de los organismos de garantía del derecho de acceso en las comunidades autónomas. Revista Jurídica de Castilla y León, Valladolid, n. 45, p. 99, mai. 2018.

70 VELASCO RICO, Clara. Reconocimiento y protección del derecho de acceso a los documentos público en Quebec: especial referencia a la Comisión de Acceso a la Información. Revista Catalana de Dret Públic, Valladolid, n. 50, p. 137-138, mai. 2015.
} 
del CTM serán elegidos "entre personas de reconocido prestigio con diez años de experiencia profesional acreditada en actividades relacionadas con el sector público, la transparencia y el acceso a la información pública"71. No obstante, hubiera sido más acertado hacer hincapié en la necesaria formación jurídica de los miembros del CTM.

Representantes de la sociedad civil. Por último, en algunas autoridades de transparencia, la normativa establece que parte de sus miembros sean representantes de la sociedad civil, del mundo laboral y productivo así como del asociacionismo. Debido a la variedad del diseño institucional de cada autoridad de transparencia ${ }^{72}$ no hay un modelo uniforme, pero es posible observar que los representantes que pertenecen a esta categoría proceden de los siguientes ámbitos: intereses económicos y sociales; asociaciones de consumidores y usuarios; representantes de consejos de participación ciudadana; ${ }^{73}$ representantes de organizaciones sindicales y empresariales.

\subsection{Forma de designación de los miembros de las autoridades de transparencia}

En palabras de Salvador Martínez, la “autonomía se garantiza sobre todo limitando o condicionando la participación del Gobierno en la elección y cese de los miembros de las "autoridades independientes»"74. Si asumimos como acertada esta consideración y la trasladamos a la configuración institucional de las autoridades de transparencia, llegaríamos a la conclusión de que sería deseable que la elección o designación de los miembros de dichas autoridades - o al menos de los órganos que tienen asignada

\footnotetext{
71 Art. 74 LTM.

72 El CTMu incorpora dos miembros del Consejo Económico y Social de la Región de Murcia - en representación de los intereses económicos y sociales y de los consumidores y usuarios-, un representante del Consejo de Participación Ciudadana, dos representantes sindicales de las centrales sindicales mayoritarias, y un representante de las organizaciones empresariales (arts. 38.5.g)-k) LTMu). El CTAr incorpora dos representantes de los agentes sociales, colectivos o asociaciones con mayor representatividad en la CA, y dos representantes de las organizaciones y asociaciones de defensa de los consumidores y usuarios legalmente constituidas (arts. 37.4.e), h) y i) LTAr). El CTCV incorpora un representante de las organizaciones empresariales, un representante de las organizaciones sindicales, un representante de las asociaciones de consumidores y usuarios, y un representante del Consejo de Participación Ciudadana (arts. 41.2.d), g), h), i), y j) LTCV). El CTAn incorpora representantes de los entes locales, las entidades representativas de las personas consumidoras y usuarias, y las entidades representativas de los intereses económicos y sociales (arts. 49.3.c), e) y f) LTAn). El CTNv incorpora tres representantes de las entidades locales de Navarra (art. 65.1.c) LTNv). Finalmente, el CTGa -como órgano colegiado adscrito al Defensor del Pueblo, institución que tiene atribuidas las competencias del CT autonómico- tiene un representante de la Federación Gallega de Municipios y Provincias (art. 33.2.c) LTGa).

73 CARMONA GARIAS, Silvia. Nuevas tendencias en la participación ciudadana en España: ¿socializando la gestión pública o socializando la responsabilidad política? A\&C - Revista de Direito Administrativo \& Constitucional, Belo Horizonte, ano 16, n. 66, p. 29-60, out./dez. 2016; SCHIER, Adriana da Costa Ricardo; MELO, Juliane Andrea de Mendes Hey. O direito à participação popular como expressão do Estado Social e Democrático de Direito. A\&C - Revista de Direito Administrativo \& Constitucional, Belo Horizonte, ano 17, n. 69, p. 127-147, jul./set. 2017.

74 SALVADOR MARTÍNEZ, María. Partidos políticos y "autoridades independientes". Revista Española de Derecho Constitucional, Madrid, n. 104, p. 90, mai./ago. 2015.
} 
la competencia de resolver las reclamaciones en materia de acceso - intervengan los parlamentos mediante fórmulas de votación con mayorías especialmente reforzadas. Desde esta perspectiva en este epígrafe se analizarán las formas de designación de los miembros de las autoridades de transparencia tal como se regulan en su correspondiente normativa.

En el modelo estatal, el presidente del CTBG es nombrado a propuesta del Ministerio de Hacienda, pero debe ser refrendado por mayoría absoluta de la comisión competente del Congreso de los Diputados ${ }^{75}$. Además, debe señalarse que será de aplicación al Presidente del CTBG el régimen jurídico previsto por la Ley 3/2015, de 30 de marzo, reguladora del ejercicio del Alto Cargo de la Administración General del Estado, por explicita inclusión en su ámbito de aplicación (art. 1.2.e). Dicho régimen conlleva una serie de garantías en términos de requisitos de idoneidad, conflictos de intereses e incompatibilidades, especialmente intensos. En cualquier caso, en la doctrina se ha criticado que la facultad de proponer el candidato a ocupar la presidencia del CTBG dependa exclusivamente del gobierno ${ }^{76}$. En cambio, el Director del CTPDAn y el Presidente de CTNv son designados por sus respectivos parlamentos autonómicos por mayoría absoluta ${ }^{77}$. Parece a priori criticable que dicha mayoría absoluta sea suficiente para asegurar el mínimo de independencia formal para un órgano de estas características (Sierra Rodríguez, 2018, p. 84), especialmente ante los supuestos de mayorías parlamentarias de una sola formación política. Por lo tanto, deben señalarse positivamente aquellos modelos en los cuales se requieren mayorías reforzadas. En este sentido, la mayoría reforzada de las tres quintas partes del parlamento autonómico se exige en varias leyes autonómicas de transparencia. Es el caso de la Ley catalana para la elección de todos los miembros de la CGAIP ${ }^{78}$, de la Comunidad Valenciana para la elección de la Comisión Ejecutiva del $\mathrm{CTCV}^{79}$, de la Comunidad de Madrid para la elección de los tres miembros del $\mathrm{CTM}^{80}$ y del Comisionado de Transparencia de Canarias ${ }^{81}$. La ley murciana exige en primera vuelta una mayoría reforzada de dos tercios de la Asamblea Regional para la designación del presidente del CTMu mientras que en segunda vuelta se rebaja a la mayoría absoluta ${ }^{82}$. En los supuestos de Galicia y Castilla y León, donde las competencias de los Comisionados de Transparencia se atribuyen a sus respectivos

75 Art. 37.1 LTBG.

76 JIMÉNEZ ASENSIO, Rafael. Instituciones de garantía de la transparencia. El Cronista Del Estado Social y Democrático de Derecho, Madrid, n. 68, p. 67, 2017.

77 Arts. 47.2 LTAn y 65.2 LTNv.

78 Art. 40.1 LTCat.

79 Art. 41 LTCV.

80 Art. 74.1 LTM.

81 Art. 59.1 LTCn.

82 Art. 38.6 LTMu. 
Defensores del Pueblo, se prevén unas mayorías cualificadas en las cámaras legislativas; en efecto, tanto el Valedor del Pueblo gallego como el Procurador del Común castellanoleonés son escogidos por tres quintas partes de sus respectivos parlamentos ${ }^{83}$. En la forma de designación de los miembros de autoridad vasca el vínculo con el gobierno es el más intenso a pesar de proclamarse la independencia del órgano. Así, el presidente de la CVAIP recaerá en un alto cargo del gobierno autonómico, en concreto, el titular de la Dirección de Atención a la Ciudanía e Innovación y Mejora de la Administración, mientras los dos vocales serán funcionarios de carrera de la administración autonómica nombrados por el Consejero de Administración Pública previa convocatoria pública ${ }^{84}$. Si se añade que el desempeño de las funciones inherentes al cargo de las personas funcionarias no tiene lugar en régimen de dedicación exclusiva sino alternando con el desempeño de las tareas propias del puesto de trabajo, la autonomía real de órgano queda virtualmente muy en entredicho. No obstante, cabe destacar por el interés que podría suponer como instrumento de selección de candidatos, la convocatoria pública. Una convocatoria pública realmente abierta a todos los expertos en materia de transparencia, podría ser una fórmula de captación a combinar con los mecanismos parlamentarios de elección mediante mayorías reforzadas que ya hemos comentado, para lograr un mayor grado de independencia y experiencia de los integrantes de las autoridades. Se registra una influencia gubernamental significativa también en la autoridad balear: la CRAIPIB está compuesta por tres miembros, con un marcado carácter técnico (juristas de reconocido prestigio con más de cinco años de experiencia en el ámbito del derecho público) pero designados por el Consejo de Gobierno a propuesta del Consejero de Presidencia ${ }^{85}$, por ende sin que el Parlamento balear intervenga.

En cualquier caso, tampoco se puede confiar en que las mayorías cualificadas garanticen la independencia de los miembros de las autoridades. Es notorio que estos mecanismos, pensados para generar grandes consensos parlamentarios y evitar la elección de personas con dependencias de partido, pueden terminar en pactos tácitos para la repartición de cargos en función de cuotas partidistas ${ }^{86}$. Parece en cualquier caso poco adecuada la fórmula empleada en la Comunidad Valenciana, donde la Comisión Ejecutiva del CTCV, que reúne las competencias más relevantes entre las cuales la de resolución de las reclamación, está constituida por "un número de miembros es

\footnotetext{
83 Art. 2.3 de la Ley 6/1984, de 5 de junio, del Valedor del Pueblo de Galicia. Art. 6.4 de la Ley 2/1994, de 9 de marzo, del Procurador del Común de Castilla y León.

84 Art. 2.1 del Decreto 128/2016, de 13 de septiembre de la CVAIP.

85 Art. 3.1 del Decreto 1/2019, de 11 de enero, regulador de la CRAIPIB.

86 DE LA NUEZ SÁNCHEZ CASCADO, Elisa. Comentario al artículo 33. In: DE LA NUEZ SÁNCHEZ CASCADO, Elisa; TARÍN QUIRÓ, Carlota (Coords.). Transparencia y buen gobierno. Comentarios a la Ley 19/2013, de 9 de diciembre, de Transparencia, Acceso a la Información Pública y Buen Gobierno. Madrid: La Ley-Wolters Kluwer, 2014.
} 
equivalente al de grupos parlamentarios con representación en Les Corts" ${ }^{177}$. En efecto, aunque sea deseable asegurar la multiplicidad de sensibilidades políticas y evitar el alejamiento de las autoridades independientes de los mecanismos democráticos de exigencia de responsabilidades ${ }^{88}$, tampoco se puede caer en la institucionalización de un sistema partidocrático de cuotas. Esta circunstancia se vuelve especialmente importante en el caso de órganos que tienen encomendada una función de control de legalidad sobre las resoluciones de acceso a la información pública en las que no cabe la consideración de argumentos de oportunidad.

Finalmente, una nota característica propia de las autoridades de transparencia con representación institucional o de la sociedad civil, es que sus miembros son designados por las propias instancias a las que representan, sin elección o referendo de la cámara legislativa.

\subsection{La inamovilidad del cargo y la tasación de los supuestos de cese de los miembros de las autoridades de trasparencia}

A lo anteriormente expuesto debe añadirse otra pieza regulatoria destinada a reforzar la independencia de las autoridades de transparencia frente a los poderes públicos hacia los cuales desempeñarán su función de control: la regulación legal previa de las garantías de inamovilidad que se asegura mediante la previsión de causas claramente tasadas para el cese de los miembros de las autoridades. Dicha regulación es una factor común a las autoridades de transparencia, tal como se desprende de su normativa reguladora. La LTBG estatal determinó que los los supuestos de cese anticipado en el cargo de sus miembros son de aplicación tanto al Presidente como a los vocales del CTBG $^{89}$, y se limitan a los siguientes supuestos: 1) Petición propia; 2) Separación acordada por el Gobierno bajo determinados supuestos: incumplimiento grave de sus obligaciones, incapacidad permanente para el ejercicio de su función, incompatibilidad sobrevenida o condena por delito doloso. El estatuto de independencia del Presidente del CTBG, a la luz de sus importantes competencias - entre ellas, recordemos, la de resolver las reclamaciones en materia de acceso - es un factor esencial para alejarlo de las interferencias políticas indebidas ${ }^{90}$. En el caso de los vocales, se añaden los supuestos de pérdida de la condición que motivó su nombramiento (la condición de diputado, senador o consejero del Tribunal de Cuentas) o la propuesta de cese por parte de las

\footnotetext{
87 Art 41.1 LTCV.

88 SALVADOR MARTíNEZ, María. Partidos políticos y "autoridades independientes". Revista Española de Derecho Constitucional, Madrid, n. 104, p. 90, mai./ago. 2015.

89 Arts. 9.3 y 15.2 del Real Decreto 919/2014 por el que se aprueba el Estatuto del CTBG.

90 SENDÍN GARCÍA, Miguel Ángel. El Consejo de transparencia y buen gobierno. Revista Jurídica de Castilla y León, Valladolid, n. 33, p. 11, mai. 2014.
} 
instituciones a las que representan en el caso de incumplimiento sobrevenido de las condiciones que justificaron su nombramiento.

El análisis de las leyes y reglamentos autonómicos que regulan las correspondientes autoridades de transparencia pone de manifiesto que en la mayoría de los casos se han reproducido, las mismas causas tasadas de cese que hemos mencionado en relación con la normativa estatal ${ }^{91}$. Puede observarse, como elemento diferencial entre el CTBG estatal y las autoridades autonómicas en las cuales el procedimiento de designación de sus miembros intervienen sus respectivos parlamentos, que en este segundo supuesto serán las cámaras legislativas las que tendrán que apreciar las causas de cese legalmente establecidas. Es interesante señalar que en la LTM, en el caso de producirse algunas causas de cese "objetivas" (condena, muerte, incapacidad, renuncia y expiración del mandato), las vacantes en el cargo serán declaradas por la Presidencia de la Asamblea, en cambio, en los demás casos que requieren una valoración de las circunstancias que así las justifiquen (por ejemplo: el incumplimiento grave de las obligaciones propias del cargo) la decisión tendrá que ser adoptada por la cámara legislativa madrileña con una mayoría reforzada de tres quintas partes ${ }^{92}$, lo que supone ciertamente una fórmula ejemplar de protección de la independencia de los consejeros del CTM. Una excepción en sentido contrario es el director del CTAn, cuya separación es acordada por el Consejo de Gobierno autonómico teniendo que ser necesariamente oída la Comisión Consultiva del CTAn ${ }^{93}$. En los dos modelos de autoridades vinculadas a los defensores del pueblo, en cuanto a los Comisionados de transparencia, cuyas funciones están atribuidas al Valedor del Pueblo y el Procurador del Común, hay que acudir a las correspondientes leyes que regulan dichos defensores ya que ahí se prevén las causas de cese que son las que hemos comentado anteriormente en los demás casos. Debe notarse que en ambos supuestos, cuando deben apreciarse negligencia notoria o incapacidad sobrevenida (Castilla y León) y notorio incumplimiento de funciones o condena mediante sentencia firme por delito doloso (Galicia), se requiere una decisión de los parlamentos autonómicos con la mayoría reforzada de tres quintas partes ${ }^{94}$. Sin embargo, ya hemos visto que en estas dos comunidades la competencia de resolver las reclamaciones en materia de acceso se asignan a las Comisiones de Transparencia; pues

\footnotetext{
91 Véase los siguientes arts: 38.6 LTMu; 10.5 del Decreto 32/2016, de 22 de marzo, del Gobierno de Aragón, por el que se aprueba el Reglamento de Organización y de Funcionamiento del CTAr; 61.1 LTCn; 47.4 LTAn, 11 y 13.2 del Decreto 434/2015 por el que regula el CTAn; 65.2 LTNv; 4.1 del Decreto 1/2019 del CRAIPIB; 76 LTM. En el caso del CTCV (arts. 84.3 y 87.2 RCTCV), su normativa excluye el incumplimiento grave de obligaciones y la condena por delito doloso. Por su parte, el CGAIP incorpora el hecho de superar los 70 años entre los supuesto de cese (art. 12.1.g del Decreto 111/2017 por el que se aprueba el reglamento de la CGAIP).

92 Art. 76.2 LTM.

93 Art. 47.4.c) LTAn.

94 Arts. 5.1 de la Ley 6/1984, de 5 de junio, del Valedor del Pueblo de Galicia y 9.1 de la Ley 2/1994, de 9 de marzo, del Procurador del Común de Castilla y León.
} 
ocurre que los miembros de dichas comisiones, con la exclusión de sus presidentes que son los Defensores del Pueblo, no tienen legalmente previstas unas causas tasadas de cese, ni su normativa de funcionamiento con rango reglamentario dice nada al respecto, por lo que se puede concluir que los miembros de estas comisiones de transparencia pueden ser cesados libremente por la autoridad que los designa: en un caso el propio Procurador del Común, en el otro el Valedor, la administración gallega o la federación de municipios gallegos en cuanto a sus propios representantes. Por último, en el caso vasco de la CVAIP en la que hay una estricta vinculación de sus tres miembros con la administración autonómica, la normativa reguladora de la Comisión establece que los dos vocales que son funcionarios de carrera nombrados por cuatro años, "únicamente podrán ser cesados por la expiración del mandato o previa instrucción del correspondiente procedimiento por la Presidencia, por incumplimiento grave de sus obligaciones, incapacidad permanente para el ejercicio de su función, incompatibilidad sobrevenida o condena por delito doloso"95. Mientras nada se dice acerca de las causas de cese de la persona que ocupa la propia Presidencia de la CVAIP.

\subsection{Mandatos, dedicación e incompatibilidades de los miembros de las autoridades de transparencia}

Para reforzar la independencia de las autoridades de transparencia y evitar los riesgos de posibles interferencias entre las autoridades de transparencia y los intereses de las mayorías políticas, es preferible que el mandato de los miembros de las citadas autoridades -o por lo menos, en caso de autoridades con estructura dual, de las personas que sean miembros de órganos con competencias para resolver las reclamaciones en materia de acceso - supere la duración de una legislatura para desacoplar temporalmente autoridades de control y poder ejecutivo y político en la dimensión temporal. A tal propósito, en la mayoría de las normativas de transparencia se establecen mandatos de cinco años: es el caso de la autoridad estatal, de la andaluza, de la catalana, de la canaria (no renovable) ${ }^{96}$, de la valenciana y de la asturiana (renovable por una sola vez ${ }^{97}$. Concretamente, el mandato de los miembros de la CTBG estatal es prorrogable por cinco años más ${ }^{98}$, al contrario del mandato no renovable del Presidente del CTBG, quien, lo recordamos, tiene la competencia para resolver las reclamaciones (art. 37 LTBG). Igual previsión se aprecia en la normativa andaluza ${ }^{99}$. En cuanto a la CTCV, se establece que el mandato es renovable para la Comisión ejecutiva y no renovable para

95 Art. 1.3 del Decreto 128/2016, de 13 de septiembre, de la CVAIP.

96 Art. 59 LTCn.

97 Arts. 65 y 67.5 LTAs.

98 Art. 15 del Real Decreto 919/2014 por el que se aprueba el Estatuto del CTBG.

99 Art. 47 LTAn y art. 13 del Decreto 434/2015 por el que se aprueba los Estatutos del CTPDAn. 
la Comisión consultiva ${ }^{100}$. Sin embargo, puesto que la Comisión ejecutiva resulta ser la competente en resolver las reclamaciones, esta solución parece algo insólita. En el caso catalán, se establece un mecanismo de renovación escalonada de la CGAIP: de acuerdo con su reglamento ${ }^{101}$, el mandato de los miembros es de cinco años, no renovable, y la Comisión se renueva parcialmente cada dos años y medio. Murcia y Castilla-La Mancha prevén un mandato de diferente duración para sus órganos: en el CTMu, el presidente el cargo del presidente es de cinco años y no es renovable, mientras que la duración del mandato de los miembros es de cuatro años ${ }^{102}$; respecto a la autoridad manchega, para la comisión ejecutiva se dispone un mandato de cinco años (renovable una vez más), que se reduce a cuatro para la comisión consultiva. La normativa de la CVAIP, del CTAr y de CTNv establecen una duración del mandato de cuatro años ${ }^{103}$. En el supuesto navarro, el mandato del Presidente no es renovable. El único caso en el que se establece una duración inferior a aquella de un mandato político es el caso de la CRAIPIB, cuyo mandato es de 3 años (art. 3.1, Decreto 1/2019). Difiere de todos los mecanismos anteriormente analizado la nueva normativa madrileña: de acuerdo con el art. 75 de la LTM, los consejeros serán elegidos por un período de seis años no renovable y la presidencia del CTPM será ejercida por un período de dos años de forma rotatoria.

En segundo lugar, los regímenes de incompatibilidades resultan esenciales para evitar que los miembros de las autoridades de transparencia incurran en conflictos de intereses o minen la imparcialidad de la autoridad. Por este motivo es importante que el régimen de incompatibilidades de los miembros de las autoridades se encuentre bien detallado en la normativa reguladora de las mismas ${ }^{104}$. Además, para fortalecer dicha imparcialidad e independencia, en algunos supuestos, las normativas de transparencia establecen para los miembros o para el presidente de la autoridad una dedicación exclusiva. En palabras de Martín Delgado, se trata de "requisitos materiales fundamentales para el ejercicio de una función cuasi-judicial como la que tienen encomendada los órganos de control en materia de transparencia"105. De hecho, la necesidad de que determinadas funciones se desvincularan del poder político fue el principal argumento que justificó, tanto en España como en otros países, la creación de lo que con el tiempo pasarían a denominarse autoridades administrativas independientes para la garantía

\footnotetext{
100 Art. 41 LTCV, arts. 84 y 87 del Decreto 105/2017 de desarrollo de la LTCV.

101 Art. 10 del decreto 111/2017 por el que se aprueba el Reglamento de la CGAIP.

102 Art. 38 LTMu.

103 Art. 2.3 del Decreto 128/2016, de 13 de septiembre de la CVAIP; Art. 10 del Decreto 32/2016 por el que se aprueba el reglamento del CTAr; Art. 65 LTNv.

104 SIERRA RODRÍGUEZ, Javier. Una crítica al diseño de los organismos de garantía del derecho de acceso en las comunidades autónomas. Revista Jurídica de Castilla y León, Valladolid, n. 45, p. 98, mai. 2018.

105 MARTíN DELGADO, Isaac. La reclamación ante el Consejo de Transparencia y Buen Gobierno: un instrumento necesario, útil y ¿eficaz? In: LÓPEZ RAMÓN, Fernando (Coord.). Las vías administrativas de recurso a debate, Madrid, p. 296, jan./mai. 2016.
} 
de ciertos sectores económicos y la protección de derechos fundamentales respecto de los intereses ejecutivos y partidistas ${ }^{106}$.

En los supuestos en los que el presidente es el órgano competente para resolver las reclamaciones contra las resoluciones en materia de acceso, su régimen de incompatibilidad resulta más estricto en comparación con los demás miembros de la autoridad. Es el caso del CTBG, en el que al presidente se reconoce dedicación exclusiva ${ }^{107}$. Aunque ni en la LTGB ni en el reglamento se concreta un régimen de incompatibilidades para su figura, al presidente se le aplican las incompatibilidades establecidas por la Ley 3/2015, de 30 de marzo, reguladora del ejercicio del Alto Cargo de la Administración General del Estado. En cuanto a la Comisión, en cambio, la condición de miembro no exige dedicación exclusiva ni da derecho a remuneración ${ }^{108}$. Un régimen mucho más preciso se encuentra en la normativa reglamentaria del CTPDAn ${ }^{109}$ : el director, al que se le reconoce dedicación exclusiva, tiene la consideración de Alto Cargo autonómico y estará sujeto al régimen de incompatibilidades y obligaciones de los Altos Cargos de la Administración de la Junta de Andalucía, "[i]gualmente, le resulta de aplicación el régimen de buen gobierno previsto en la [LTBG estatal]". Además se detallan una serie de estrictas incompatibilidades políticas y de desempeño de puestos directivos que se aplican al Director del CTPDAn: el ejercicio de cualquier cargo electo o de designación política; el desarrollo de cualquier cargo o puesto en las Administraciones Públicas o sus entidades públicas o privadas adscritas o dependientes; la representación de cualquier Administración en los órganos de gobierno o consejos de dirección de empresas de capital público; la afiliación o el ejercicio de funciones de dirección o ejecutivas en partidos políticos, organizaciones sindicales o empresariales; el ejercicio de cualquier cargo o puesto de dirección o ejecutivas en fundaciones o asociaciones relacionadas con las competencias del Consejo; tener directa o indirectamente intereses en empresas, entidades o sociedades cuyo objeto social o actividad estén relacionados con las competencias del Consejo. En el caso del CTAs, en cambio, el art. 65 de la LTAs establece simplemente que el Presidente tiene la condición de alto cargo, mientras que en el supuesto del CTCn, unipersonal, el régimen de incompatibilidades resulta ser particularmente reforzado. A tal propósito, el art. 60 LTCn, dispone que "[e]l cargo de comisionado o comisionada de Transparencia y Acceso a la Información Pública es incompatible con todo mandato representativo, con todo cargo político o actividad de propaganda política, con la permanencia en el servicio activo de cualquier Administración pública, con la afiliación a un partido político o sindicato, con el desempeño de

\footnotetext{
106 RALLO LOMBARTE, Artemi, La Constitucionalidad de las Administraciones Independientes. Madrid: Tecnos, Madrid, p. 65-151, 2002.

107 Art. 11 del Real Decreto 919/2014 por el que se aprueba el Estatuto del CTBG.

108 Art. 36.3 LTGB

109 Art. 9 del Decreto 434/2015, de 29 de septiembre, por el que se aprueban los Estatutos del CTPDAn.
} 
funciones directivas en un partido político o en un sindicato, asociación o fundación y con el empleo al servicio de los mismos, con el ejercicio de las carreras judicial y fiscal y con cualquier actividad profesional, mercantil o laboral". En cuanto al presidente del CTMu y del CTNv, las relativas normativas disponen la incompatibilidad con la pertenencia a un partido político, incluyendo los cuatros años anteriores a su elección ${ }^{110}$.

En tercer lugar, en los casos del CTPDAn, del CTAs, del CTMu, y del CTNv para los miembros de los consejos no se establecen remuneraciones, se prevén únicamente indemnizaciones o dietas ${ }^{111}$. La falta de retribución es característica también para los miembros de la CRAIPIB ${ }^{112}$, del CTAr ${ }^{113}$, del CTCV ${ }^{144}$; sin embargo, mientras que en estos últimos dos dos supuestos no se establece un régimen de incompatibilidades, ser miembros de la CRAIPIB es incompatible con el ejercicio de cualquier cargo electivo o de designación política en una institución o ente público ${ }^{115}$, se establece según la normativa balear una indemnización por asistencia a cada sesión ${ }^{116}$. Esta falta de retribución, al contrario de ser vista como una virtud pública, debería considerarse como un factor de preocupación; en efecto, de acuerdo con Jiménez Asensio: "no es fácil que nadie se dedique "por afición" a controlar efectivamente al poder"117. Por tal motivo, surge un factor potencial de riesgo para el funcionamiento imparcial de la autoridad. En conclusión, sería deseable que quién ocupa ostenta la condición de miembro de un autoridad de transparencia sea un experto que lo haga en régimen de dedicación absoluta, con un estricto régimen de incompatibilidades y que por su función reciba una adecuada remuneración.

En la normativa de Castilla-La Mancha se detalla un régimen diferenciado para la Comisión Ejecutiva y la Consultiva: solo en relación con la primera se dispone una dedicación exclusiva y un régimen de incompatibilidades ${ }^{118}$. Para las autoridades con

110 En el caso del CTMu, el cargo de presidente es incompatible, además con el desempeño de cualquiera de los puestos señalados en el artículo 14.2 de la LTMu. En el caso del CTNv, el cargo de presidente es incompatible con cualquiera de los cargos a los que se refiere la legislación sobre incompatibilidad de los miembros del Gobierno de Navarra y de los altos cargos de la Administración Foral de Navarra.

111 Art. 9.2 de los Estatutos del CTPDAn; Art. 65 LTAs; Art. 38.8 LTMu; Art. 65.3 LTNv.

112 Perciben solo una indemnización de $360 €$ por la asistencia a cada sesión formalmente convocada e indemnizaciones para los gastos de desplazamiento a estas.

113 Art. 15 del Reglamento de organización y funcionamiento del CTAr.

114 Arts. 80 y 87 del Decreto de desarrollo de la LTCV.

115 Art. 3.2, Decreto 1/2019 regulador de la CRAIPIB.

116 Disposición adicional primera del Decreto 1/2019 regulador de la CRAIPIB.

117 JIMÉNEZ ASENSIO, Rafael. Instituciones de garantía de la transparencia. El Cronista Del Estado Social y Democrático de Derecho, Madrid, n. 68, p. 67, 2017; MARTín DELGADO, Isaac. La configuración legal de los consejos autonómicos de transparencia: algunos riesgos para el ejercicio de su función de control. Dilemata, Madrid, n. 27, p. 272, abr. 2018.

118 Art. 9.2 del Reglamento 2018/8275 de organización y funcionamiento del CTCM: “El presidente y los adjuntos de la Comisión Ejecutiva quedarán sujetos al mismo régimen de incompatibilidades establecido en la ley reguladora del régimen jurídico del Consejo de Gobierno y el de sus miembros". 
un perfil más técnico, como la catalana y la madrileña, las normativas disponen una dedicación exclusiva. En el caso catalán, el régimen de incompatibilidades es el propio del personal al servicio de las administraciones públicas; además los miembros quedan asimilados a la condición de alto cargo a efectos retributivos, ejercen el cargo en régimen de dedicación exclusiva, y están sujetos al régimen de incompatibilidades dispuesto en la misma LTCat"119. En cuanto a la CTM, el art. 75.1 LTM establece que "El cargo de presidente y consejero será incompatible con todo cargo o empleo en la Administración pública en situación de servicio activo salvo la actividad docente, con el desempeño de cualquier cargo público o político, con todo mandato representativo, con el desempeño de funciones directivas en un partido político o en un sindicato, asociación o fundación y con el empleo al servicio de los mismos, con el ejercicio activo de las carreras judicial y fiscal y con cualquier actividad profesional, mercantil o laboral", por lo cual se entiende que se trata de cargos con dedicación exclusiva.

Finalmente, en los casos castellanoleonés y gallego, se tiene que hacer referencia a las normativas de los respectivos Defensores del Pueblo. En cuanto al Valedor del Pueblo, su cargo es incompatible con todo mandato representativo, cargo político o actividad de propaganda política; con la permanencia en servicio activo de cualquier administración pública; con la condición de miembro de partido político o con el desempeño de funciones directivas en un partido, sindicato, asociación o fundación, o con el empleo al servicio de los mismos; con el ejercicio de las carreras judicial y fiscal o de cualquier actividad profesional, judicial, mercantil o laboral ${ }^{120}$. Compatibilidades similares prevé la normativa del Procurador del Común de Castilla y León. Este último, sin embargo, puede optar por desempeñar sus funciones en régimen de dedicación exclusiva o parcial y, en el segundo caso, deberá pedir autorización a la Comisión Parlamentaria de Relaciones con el Procurador del Común ${ }^{121}$.

\section{MEDIOS ECONÓMICOS, MATERIALES Y PERSONALES DE LAS AUTORIDADES DE TRANSPARENCIA}

Las garantías formales relativas al funcionamiento de las autoridades de transparencia resultan fundamentales para dotar las mismas de autonomía. A tal propósito, consideramos oportuno analizar tanto la disponibilidad de medios económicos y materiales propios, como la autonomía financiera de la autoridad de transparencia estatal y de las autonómicas. Asimismo, se hará referencia a los medios personales.

\footnotetext{
119 Arts. 40.4 LTCat y 11 del decreto $111 / 2017$ por el que se aprueba el Reglamento de la CGAIP.

120 Art. 7 LVP.

121 Art. 7, Resolución de 20 de febrero de 2014, de la Mesa de las Cortes de Castilla y León, por la que se aprueba el Reglamento de Organización y Funcionamiento del Procurador del Común de Castilla y León.
} 
Huelga recordar que la LTGB y la mayoría de las citadas leyes autonómicas de transparencia han sido aprobadas en circunstancias de recesión económica y de post-crisis, por los que los principios de estabilidad presupuestaria, de sostenibilidad financiera y del límite del gasto público ${ }^{122}$ se encuentran conjugados, en diferentes formas, en las leyes de aprobación o en los estatutos de creación de sendas autoridades. Así, en cuanto al CTBG, la Disposición Adicional del Real Decreto 919/2014, de 31 de octubre, por el que se aprueba el Estatuto del Consejo de Transparencia y Buen Gobierno, dispone expresamente la prohibición de incremento del gasto público para la creación del CTBG: "La creación y puesta en funcionamiento del Consejo de Transparencia y Buen Gobierno no podrán suponer incremento de dotaciones, retribuciones, u otros gastos de personal ni, por otros conceptos, incremento neto de estructura o de personal al servicio del sector público estatal. El Consejo se dotará exclusivamente mediante la redistribución de efectivos del Ministerio de Hacienda y Administraciones Públicas, sus organismos y entidades públicas, y su funcionamiento se atenderá con los medios materiales y personales de que dispone actualmente la Administración". De igual tenor resultan la DA $2^{\text {a }}$ de la LTCL ${ }^{123}$, la DA $5^{\text {a }}$ LTAs $^{124}$ y la DA 4a del Decreto 32/2016, de 22 de marzo, del Gobierno de Aragón, por el que se aprueba el Reglamento de Organización y de Funcionamiento del Consejo de Transparencia de Aragón ${ }^{125}$.

En la DF $1^{\text {a }}$ del Decreto 434/2015, de 29 de septiembre, por el que se aprueban los Estatutos del Consejo de Transparencia y Protección de Datos de Andalucía, en cambio, se hace referencia a los citados principios, pero sin establecer una negativa explicita al incremento del gasto público.

\subsection{Medios económicos y gestión presupuestaria}

Salvador Martínez remarca la importancia de autonomía financiera para garantizar autonomía a las autoridades de transparencia. De acuerdo con la autora "[e]sta autonomía suele considerarse menor, pero no lo es, porque, si la financiación depende de una decisión del Gobierno o del Parlamento, como ocurre por regla general, esto otorga una importante vía de influencia a estos órganos y puede suponer, como ha

122 Vid. Ley Orgánica 2/2012, de 27 de abril, de Estabilidad Presupuestaria y Sostenibilidad Financiera.

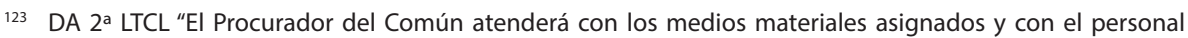
actualmente existente, sin incremento de gasto, el ejercicio de las funciones del Comisionado y de la Comisión de Transparencia".

124 "La adaptación de las estructuras orgánicas y de las relaciones de puestos de trabajo a lo dispuesto en esta Ley se hará sin incremento de plantilla, ni de los gastos de personal, en cumplimiento de lo previsto en las correspondientes Leyes

del Principado de Asturias de Presupuestos Generales y de conformidad con los principios de estabilidad presupuestaria y sostenibilidad financiera".

125 "La creación y puesta en funcionamiento del Consejo de Transparencia de Aragón no podrá suponer incremento de dotaciones, retribuciones u otros gastos de personal ni, por otros conceptos, incremento neto de estructura o de personal al servicio de la Administración de la Comunidad Autónoma de Aragón". 
sucedido ya en algún caso, que el Parlamento o el Gobierno lleguen a paralizar la actividad de una «autoridad independiente» negándose a financiarla"126.

El análisis de la normativa estatal muestra que, además de las asignaciones que se establezcan anualmente con cargos a los Presupuestos Generales del Estado, los medios económicos del CTBG se componen por otros ingresos "autónomos". Lo mismo establecen las normativas del CTPDAn andaluz y del CTNv navarro. En cuanto a la autoridad estatal, se trata de las subvenciones y aportaciones que se puedan conceder a su favor, procedentes de fondos específicos de la Unión Europea o de otros organismos internacionales, los bienes y valores que constituyan su patrimonio, así como los productos y rentas del mismo y de cualesquiera otros que legalmente puedan serle atribuidos (art. 21 LTBG). En cuanto a la andaluza, además de las subvenciones, constan los rendimientos de las publicaciones, estudios y demás actuaciones del Consejo, las contraprestaciones derivadas de los convenios firmados por el Consejo, los rendimientos de los bienes o valores de su patrimonio y cualesquiera otros que pudiera recibir según lo previsto en el Texto Refundido de la Ley General de la Hacienda Pública de la Junta de Andalucía (art. 19 Decreto 434/2015, de 29 de septiembre, por el que se aprueban los Estatutos del CTPDAn). Una previsión parecida se halla también en el art. 71 de la LTNv.

Con referencia al presupuesto, una cierta autonomía en la gestión presupuestaria se podría observar en las disposiciones relativas al CTBG (arts. 21 y 22 LTGB). El art. 22 establece, entre otras cosas, que anualmente el CTBG elaborará - y su presidente aprobará - un anteproyecto de presupuesto, con la estructura que señale el Ministerio de Hacienda y Administraciones Pública, aunque posteriormente lo remitirá a éste para su integración en los Presupuestos Generales del Estado (de acuerdo con lo previsto en la Ley 47/2003, de 26 de noviembre). Además se establece que "[e]l presupuesto tendrá carácter limitativo por su importe global y carácter estimativo para la distribución de los créditos por categorías económicas, con excepción de los correspondientes a gastos de personal que, en todo caso, tendrán carácter limitativo y vinculante por su cuantía total, y de las subvenciones nominativas y las atenciones protocolarias y representativas, que tendrán carácter limitativo y vinculante cualquiera que sea el nivel de la clasificación económica al que se establezcan". De tal manera que, excluyendo las categorías establecidas, la distribución interna del gasto tiene naturaleza de previsión (estimativa), que puede ser decidida por el CTBG (y aprobada por su presidente). Sin embargo, si bien en teoría de las disposiciones citadas emerge una vocación autónoma del presupuesto del CTBG ${ }^{127}$, la praxis suele ser diferente, puesto que la estructura de

126 SALVADOR MARTínEZ, María. Partidos políticos y "autoridades independientes". Revista Española de Derecho Constitucional, Madrid, n. 104, p. 91, mai./ago. 2015.

127 SIERRA RODRÍGUEZ, Javier. Una crítica al diseño de los organismos de garantía del derecho de acceso en las comunidades autónomas. Revista Jurídica de Castilla y León, Valladolid, n. 45, p. 82, mai. 2018. 
los presupuestos resulta decidida por el Ministerio de Hacienda, sin que el CTBG sea siquiera consultado ${ }^{128}$.

La posibilidad para la autoridad de transparencia de elaborar y aprobar su propio anteproyecto de presupuesto, que posteriormente será incorporado en el presupuesto de la Comunidad Autónoma correspondiente, se especifica en el anteriormente citado decreto andaluz (art. 20) y en la ley murciana, por la que se prevé una sección propia dentro de los Presupuestos Generales de la Comunidad Autónoma (art. 38bis LTMu). En cuanto a la Castilla-La Mancha el procedimiento resulta diferente ya que la aprobación del anteproyecto no será a cargo del CTCM sino que será aprobado, a propuesta de la Presidencia de la Comisión Ejecutiva, por la Mesa de las Cortes de Castilla-La Mancha, que lo remitirá a la consejería con competencias en materia de hacienda para su integración en el Proyecto de Ley de Presupuestos Generales de la Junta de la Comunidad de Castilla-La Mancha (art. 17 del Reglamento de Organización y Funcionamiento del Consejo Regional de Transparencia y Buen Gobierno, 2018/8275]. Esto se justifica en cuanto el CTCM no tiene un patrimonio propio, independiente del de las Cortes de Castilla-La Mancha: sus bienes y derechos se integran dentro del inventario general de bienes y derechos de las Cortes (art. 20 del citado reglamento). Lo mismo se puede argumentar del CTAr, por el que no está prevista partida presupuestaria propia y diferenciada y cuya financiación está prevista con cargo al Departamento competente en materia de transparencia ${ }^{129}$.

Con referencia a la normativa catalana cabe mencionar que el Decreto 111/2017, de 18 de julio, por el que se aprueba el Reglamento de la CGDAIP prevé la existencia de una partida específica dentro del presupuesto del Departamento al que se adscribe (art 52). Además, dispone que la Comisión propone anualmente los recursos necesarios para desarrollar su actividad en función de las reclamaciones tramitadas y de la actividad desarrollada. Si bien es el Gobierno el que "debe dotar a la Comisión de Garantía del Derecho de Acceso a la Información Pública de los medios personales y materiales necesarios para garantizar su independencia orgánica y funcional en el ejercicio de sus funciones", esto se hará previa propuesta anual del presidente de la CGDAIP de los recursos y medios personales y materiales necesarios para el ejercicio adecuado de sus funciones (art. 51). Con este cambio, de acuerdo con Martín Delgado ${ }^{130}$, el modelo de

\footnotetext{
128 Fuente: "El Consejo de Transparencia dejó sin gastar el 37\% de su presupuesto por un mal reparto de Hacienda", publicado en Eldiario.es en fecha 16 de febrero de 2019. Disponible en: <https://www.eldiario.es/sociedad/Hacienda-Consejo-Transparencia-utilizar-presupuesto_0_865463624.html>.

129 Art. 15 Decreto 32/2016, de 22 de marzo, del Gobierno de Aragón, por el que se aprueba el Reglamento de Organización y de Funcionamiento del Consejo de Transparencia de Aragón.

130 MARTÍN DELGADO, Isaac. La configuración legal de las autoridades de transparencia. In: MARTíN DELGADO, Isaac; GUICHOT REINA, Emilio; CERRILLO MARTÍNEZ, Agustí. Configuración legal, actuación y funciones de las autoridades de transparencia. Algunas propuestas de mejora. Barcelona-Madrid: Fundación Democracia y Gobierno Local, 2019, p. 59.
} 
autorización de gastos deja el paso al modelo de existencia de presupuesto propio con capacidad y autonomía para ejecutarlo. Similar resulta la disposición valenciana relativa a la CTCV (art. 77, Decreto 105/2017, de 28 de julio, del Consell, de desarrollo de la Ley $2 / 2015$, de 2 de abril, de la Generalitat, en materia de transparencia y de regulación del CTCV).

En cuanto a las restantes autoridades, no se observa una concreción o un grado de detalle legal como en las anteriormente analizadas; sin embargo, la normativa navarra (art. 67 LTNv) y canaria (art. 62.2 LTCn) manifiestan una atribución de recursos materiales y personales facilitados por la institución a la que está adscrita cada autoridad de transparencia.

Finalmente, respecto a los dos casos de autoridades vinculadas a los Defensores del Pueblo - los CTVP/ CTGa gallego y el CTPC/ CTCL de Castilla y León -, ambas normativas establecen que sendas autoridades de trasparencia contarán con los medios materiales y personales asignados a las defensorías.

\subsection{Medios personales}

En cuanto a los medios personales, la autoridad de transparencia estatal, así como la andaluza disponen de su propia relación de puestos de trabajo (RPT). La CTBG dispone de una relación propia de puestos de trabajo (art 26 LTBG), propuesta por el presidente a los órganos competentes de la Administración General del Estado, en la que constarán los puestos que deban ser desempeñados en exclusiva por personal funcionario ${ }^{131}$, así como la denominación de los puestos, los grupos de clasificación profesional, los cuerpos o escalas, en su caso, a que estén adscritos, los sistemas de provisión de puestos y las retribuciones complementarias. De acuerdo con el citado artículo, el resto de puestos de trabajo serán desempeñados, con carácter general, por personal funcionario y solo excepcionalmente podrán existir puestos de personal laboral. Una previsión parecida es introducida por el art. 16 del Decreto 434/2015, de 29 de septiembre, por el que se aprueban los Estatutos del CTPDAn. En el caso catalán, los puestos de trabajo de la CGAIP constan en la RPT del departamento en el cual se adscribe (art. 53 del Reglamento de la CGAIP), con la naturaleza, la denominación, el número de plazas por grupos y niveles, la forma de provisión y el resto de elementos que hay que incluir, determinados de acuerdo con la normativa aplicable al personal al servicio de la Administración de la Generalitat. En cuanto a la autoridad asturiana, el art. 63.2 de la LTAs dispone que el CTAs contará con el personal funcionario del Principado de Asturias que le sea adscrito.

131 "[...] por consistir en el ejercicio de las funciones que impliquen la participación directa o indirecta en el ejercicio de potestades públicas y la salvaguarda de los intereses generales del Estado y de las Administraciones Públicas" Art. 26 LTBG. 
Muchas normativas, en cambio, hacen limitada referencia solo a la suficiencia de medios facilitados por la institución a las que las autoridades están adscritas, es decir apoyo jurídico, técnico y administrativo y medios personales que sean necesarios: es el caso de la normativa canaria ${ }^{132}$, navarra ${ }^{133}$ y madrileña ${ }^{134}$. A tal propósito, para el CTCV valenciano se establece que el soporte administrativo será prestado por una unidad administrativa de la consejería competente en materia de transparencia y acceso a la información pública (art. 39 LTCV y art. 79 del Reglamento del CTCV).

El modelo previsto en la destinación de personal por CTCM de Castilla-La Mancha, en cambio, es mixto, como se recaba por el art. 22 del Reglamento de Organización y Funcionamiento del Consejo Regional de Transparencia y Buen Gobierno: por un lado, será el personal de las Cortes de Castilla-La Mancha a prestar apoyo jurídico, técnico y administrativo al CTCM, por el otro, el CTCM contará, además, con los medios personales necesarios conforme a la relación de puestos de trabajo que apruebe la Mesa, a propuesta de la Presidencia de la Comisión Ejecutiva, previo informe del letrado mayor. En el caso aragonés, el art. 2 del Reglamento del CTAr establece que el departamento al que se encuentra adscrito "habrá de poner a su disposición los medios personales, técnicos y materiales necesarios para el ejercicio de sus funciones".

Finalmente, las autoridades de transparencia de Galicia y Castilla y León disponen del personal propio de las correspondientes defensorías del pueblo (art. 6 del Reglamento interno de la CTGa y art. 15 de la LTCL).

\section{REFLEXIONES CONCLUSIVAS}

La adopción en toda España de normativas específicas en materia de transparencia y la creación, tanto a nivel estatal como en la mayoría de Comunidades Autónomas, de autoridades de control del cumplimiento de dicha normativa $-y$, muy especialmente, dotadas de competencias para resolver las reclamaciones en materia de acceso sustitutivas del régimen ordinario de los recursos administrativos - apunta al reforzamiento de la aproximación regulatoria en materia de prevención de la corrupción ${ }^{135}$. Se ha expuesto que los mandatos resultantes de las previsiones legislativas constituyen uno de los tres requisitos necesarios para poder inferir que las leyes y las autoridades de transparencia españolas se encuadran en el marco teórico de la

132 Art. $62.2 \mathrm{LTCn}$.

133 Art. 67 LTNV.

134 Art. 73.2 LTM.

135 DE BENEDETTO, Maria. La comprensión y la prevención de la corrupción: un enfoque regulatorio. In: PONCE SOLÉ, Juli; CERRILLO I MARTÍNEZ, Agustí. Innovación en el ámbito del buen gobierno regulatorio: ciencias del comportamiento, transparencia y prevención de la corrupción. Madrid: INAP, 2017, p. 71-85; LEAL, Mônia Clarissa Hennig; MORAES, Maria Valentina de. Relações entre estado, Administração Pública e sociedade: a corrupção como fenômeno multicultural e a afetação dos direitos fundamentais. A\&C - Revista de Direito Administrativo \& Constitucional, Belo Horizonte, ano 18, n. 74, p. 175-192, out./dez. 2018. 
regulation-inside-government. Sin embargo, era necesario comprobar el cumplimiento de otros dos criterios: Por una parte, la existencia de organismos públicos con capacidad de incidir en la actividad de otros ("to shape the activities of another [bureaucracy]"). En este sentido parece que la asignación de la mencionada función de control de las resoluciones en materia de acceso, junto con las demás competencias de evaluación, información, asesoramiento y formación, cumple el segundo requisito. Por otra parte, el tercer requisito - "some degree of organizational separation between the 'regulating' bureaucracy and the 'regulatee $e^{\prime \prime \prime}$ - atañe la garantía de la independencia de las autoridades de transparencia; ésta es cuestión en la que se ha centrado el foco analítico del presente trabajo.

La siguiente tabla contiene información sobre la naturaleza jurídica de las autoridades de transparencia, su adscripción, su composición y la duración del mandato de sus miembros, con especial atención a la duración en el cargo de los miembros del órgano colegiado o del órgano unipersonal que ostenta la competencia para resolver las reclamaciones en materia de transparencia. Estas informaciones, junto con los demás elementos que se han analizados en el texto, relativos a la forma de designación, la inamovilidad, las causas de cese, la dedicación y las incompatibilidades de los miembros de las autoridades, así como la disposición de medios necesarios para llevar a cabo las funciones atribuidas, nos permiten formular una serie de reflexiones conclusivas.

\begin{tabular}{|c|c|c|c|}
\hline \multicolumn{4}{|c|}{ TABLA 1. LEYES Y AUTORIDADES DE TRANSPARENCIA } \\
\hline Ley estatal de transparencia: & $\begin{array}{l}\text { Acrónimo } \\
\text { utilizado } \\
\text { (leyes) }\end{array}$ & $\begin{array}{l}\text { Autoridades de } \\
\text { Transparencia }\end{array}$ & $\begin{array}{l}\text { Acrónimo } \\
\text { utilizado } \\
\text { (autoridades) }\end{array}$ \\
\hline $\begin{array}{l}\text { Ley 19/2013, de } 9 \text { de diciembre, de } \\
\text { transparencia, acceso a la información } \\
\text { pública y buen gobierno }\end{array}$ & LTBG & $\begin{array}{l}\text { Consejo de } \\
\text { Transparencia y } \\
\text { Buen Gobierno }\end{array}$ & CTBG \\
\hline \multicolumn{4}{|l|}{$\begin{array}{l}\text { Leyes autonómicas de transparencia } \\
\text { (orden cronológico): }\end{array}$} \\
\hline $\begin{array}{l}\text { 17) Ley } 4 / 2011 \text {, de } 31 \text { de marzo, de } \\
\text { buena administración y buen } \\
\text { gobierno de las Islas Baleares }\end{array}$ & LBAIB & $\begin{array}{c}\text { Comisión para las } \\
\text { Reclamaciones } \\
\text { de Acceso a la } \\
\text { Información } \\
\text { Pública de las Islas } \\
\text { Baleares (creada } \\
\text { por el Decreto } \\
\text { 1/2019y no por la } \\
\text { LBAIB) }\end{array}$ & CRAIPIB \\
\hline $\begin{array}{l}\text { 18) 2) Ley } 4 / 2013 \text {, de } 21 \text { de mayo, de } \\
\text { Gobierno Abierto de Extremadura }\end{array}$ & LGAEx & -- & -- \\
\hline
\end{tabular}




\begin{tabular}{|c|c|c|c|c|}
\hline & $\begin{array}{l}\text { Ley } 1 / 2014 \text {, de } 24 \text { de junio, } \\
\text { de Transparencia Pública de } \\
\text { Andalucía }\end{array}$ & LTAn & $\begin{array}{l}\text { Consejo de } \\
\text { Transparencia } \\
\text { y Protección } \\
\text { de Datos de } \\
\text { Andalucía }\end{array}$ & CTPDAn \\
\hline 20) & $\begin{array}{l}\text { Ley } 3 / 2014 \text {, de } 11 \text { de septiembre, } \\
\text { de Transparencia y Buen Gobierno } \\
\text { de La Rioja }\end{array}$ & LTL & -- & -- \\
\hline 21) & $\begin{array}{l}\text { Ley } 12 / 2014 \text {, de } 16 \text { de diciembre, } \\
\text { de Transparencia y Participación } \\
\text { Ciudadana de Murcia }\end{array}$ & LTMu & $\begin{array}{l}\text { Consejo de } \\
\text { Transparencia } \\
\text { de la Región de } \\
\text { Murcia }\end{array}$ & $\mathrm{CTMu}$ \\
\hline 22) & $\begin{array}{l}\text { Ley } 12 / 2014 \text {, de } 26 \text { de diciembre, } \\
\text { de Transparencia y de Acceso a la } \\
\text { Información Pública de Canarias }\end{array}$ & LTCn & $\begin{array}{l}\text { Comisionado de } \\
\text { Transparencia } \\
\text { y Acceso a la } \\
\text { Información } \\
\text { Pública }\end{array}$ & CTCn \\
\hline 23) & $\begin{array}{l}\text { Ley 19/2014, de } 29 \text { de diciembre, } \\
\text { de Transparencia, Acceso a la } \\
\text { Información Pública y Buen } \\
\text { Gobierno de Cataluña }\end{array}$ & LTCat & $\begin{array}{l}\text { Comisión de } \\
\text { Garantía de } \\
\text { Acceso a la } \\
\text { Información } \\
\text { Pública de } \\
\text { Cataluña }\end{array}$ & CGAIP \\
\hline 24) & $\begin{array}{l}\text { Ley } 3 / 2015 \text {, de } 4 \text { de marzo, de } \\
\text { Transparencia y Participación } \\
\text { Ciudadana de Castilla y León }\end{array}$ & LTCL & $\begin{array}{l}\text { Comisionado de } \\
\text { Transparencia; } \\
\text { Comisión de } \\
\text { Transparencia }\end{array}$ & $\begin{array}{l}\text { CTPC } \\
\text { CTCL }\end{array}$ \\
\hline 25) & $\begin{array}{l}\text { Ley 8/2015, de } 25 \text { de marzo, de } \\
\text { Transparencia de la Actividad } \\
\text { Pública y Participación Ciudadana } \\
\text { de Aragón }\end{array}$ & LTAr & $\begin{array}{l}\text { Consejo de } \\
\text { Transparencia de } \\
\text { Aragón }\end{array}$ & CTAr \\
\hline 26) & $\begin{array}{l}\text { Ley } 2 / 2015 \text {, de } 2 \text { de abril, de la } \\
\text { Generalitat, de Transparencia, } \\
\text { Buen Gobierno y Participación } \\
\text { Ciudadana de la Comunidad } \\
\text { Valenciana }\end{array}$ & LTCV & $\begin{array}{l}\text { Consejo de } \\
\text { Transparencia, } \\
\text { Acceso a la } \\
\text { Información } \\
\text { Pública y Buen } \\
\text { Gobierno }\end{array}$ & CTCV \\
\hline 27) & $\begin{array}{l}\text { Ley } 1 / 2016 \text {, de } 18 \text { de enero, de } \\
\text { Transparencia y Buen Gobierno de } \\
\text { Galicia }\end{array}$ & LTGa & $\begin{array}{l}\text { Comisionado de } \\
\text { Transparencia } \\
\text { (CTVP); Comisión } \\
\text { de Transparencia } \\
\text { (CTGa) }\end{array}$ & $\begin{array}{l}\text { CTVP } \\
\text { CTGa }\end{array}$ \\
\hline
\end{tabular}




\begin{tabular}{|c|c|c|c|c|}
\hline 28) & $\begin{array}{l}\text { Ley } 4 / 2016 \text {, de } 15 \text { de diciembre, de } \\
\text { Transparencia y Buen Gobierno de } \\
\text { Castilla-La Mancha }\end{array}$ & LTCM & $\begin{array}{l}\text { Consejo Regional } \\
\text { de Transparencia y } \\
\text { Buen Gobierno }\end{array}$ & CRTCM \\
\hline 29) & $\begin{array}{l}\text { Ley } 1 / 2018 \text {, de } 21 \text { de marzo, de } \\
\text { Transparencia de la Actividad } \\
\text { Pública de Cantabria }\end{array}$ & LTCb & $\begin{array}{l}\text { Consejo de } \\
\text { Transparencia } \\
\text { de Cantabria } \\
\text { (previsto) }\end{array}$ & $\mathrm{CTCb}$ \\
\hline 30) & $\begin{array}{l}\text { Ley Foral 5/2018, de } 17 \text { de mayo, } \\
\text { de Transparencia, Acceso a la } \\
\text { Información Pública y Buen } \\
\text { Gobierno de Navarra }\end{array}$ & LTNv & $\begin{array}{l}\text { Consejo de } \\
\text { Trasparencia de } \\
\text { Navarra }\end{array}$ & CTNv \\
\hline 31) & $\begin{array}{l}\text { Ley } 8 / 2018 \text {, de } 14 \text { de septiembre, } \\
\text { de Transparencia, Buen Gobierno y } \\
\text { Grupos de Interés de Asturias }\end{array}$ & LTAs & $\begin{array}{l}\text { Consejo de } \\
\text { Transparencia y } \\
\text { Buen Gobierno } \\
\text { (previsto) }\end{array}$ & CTAs \\
\hline \multirow[t]{2}{*}{ 32) } & $\begin{array}{l}\text { Ley } 10 / 2019 \text {, de } 10 \text { de abril, de } \\
\text { Transparencia y Participación de la } \\
\text { Comunidad de Madrid }\end{array}$ & LTM & $\begin{array}{l}\text { Consejo de } \\
\text { Transparencia y } \\
\text { Participación }\end{array}$ & CTM \\
\hline & & & $\begin{array}{l}\text { Comisión Vasca } \\
\text { de Acceso a la } \\
\text { información } \\
\text { Pública (Creada } \\
\text { por el Decreto } \\
\text { 128/2016, de } 13 \\
\text { de septiembre) }\end{array}$ & CVAIP \\
\hline
\end{tabular}

Este estudio se ha centrado en la importancia del diseño institucional resultante de configuración normativa, en la medida en que puede favorecer (o dificultar) la independencia real de las autoridades de transparencia. La heterogeneidad de las fórmulas empleadas por los legisladores pone de manifiesto que no hay un modelo único a seguir para lograr la independencia de estas autoridades respecto del poder político y de los ejecutivos, así como el no sometimiento a instrucciones jerárquicas y la imparcialidad de sus decisiones. Sin embargo, el análisis llevado a cabo ha permitido identificar elementos y factores cuya existencia permite responder con mayor adecuación a las finalidades expuestas.

En cuanto a la cuestión de la naturaleza jurídica de las autoridades de transparencia se puede afirmar que la personalidad jurídica propia resulta la condición formal más adecuada pero no necesariamente suficiente para garantizar su independencia. No obstante, no deja de ser una característica conveniente, en la medida en que se puede asociar a otros factores que incrementan el nivel de independencia de la autoridad, como la existencia de una dotación de recursos adecuada.

El sistema de designación parlamentaria de los miembros de las autoridades de transparencia mediante mayorías reforzadas, además de otorgar mayor legitimidad a 
las propias autoridades, refuerza la independencia de sus miembros introduciendo $a b$ initio una garantía de separación respecto del poder ejecutivo, cuyas actuaciones serán mayoritariamente objeto de control. En este mismo sentido, también la competencia y el sistema para proponer candidatos para las autoridades debería alinearse con un modelo plural y abrirse a fórmulas inusuales en nuestro ordenamiento, como la convocatoria pública de expertos.

La especialización es un requisito legal derivado del art. 112 LPAC, a causa de la sustitución del régimen ordinarios de los recursos administrativos por el sistema de reclamación ante las autoridades de transparencia. Como consecuencia, debe insistirse en el necesario perfil técnico-jurídico de los miembros del órgano llamado a conocer de la legalidad de las reclamaciones contra las resoluciones expresas o presuntas en materia de acceso a la información pública.

La garantía de independencia requiere también evitar que los mandatos de los miembros de las autoridades de transparencia coincidan con el período de cada legislatura, al fin de reducir cualquier riesgo de sumisión política.

El ejercicio de una importante función de control, que puede calificarse de cuasi judicial para aquellas autoridades de transparencia que asumen las competencias para resolver las reclamaciones en materia de acceso a la información pública, aconseja claramente que se adopte un régimen de dedicación exclusiva y un severo régimen de incompatibilidades para los miembros de tales autoridades. Dicho régimen debe prevenir riesgos de conflicto de intereses profesionales, personales, ideológicos y económicos que puedan afectar a la imparcialidad de las decisiones. Además, es importante establecer incompatibilidades tanto durante el ejercicio del cargo como con posterioridad a su cese.

Es preciso que los miembros de las autoridades de transparencia dispongan de un estatuto de inamovilidad y que exista una estricta tipificación de los supuestos de cese, al fin de proteger el ejercicio del cargo de cualquier interferencia o posible amenaza de interrupción de su mandato.

En materia de diseño institucional de las autoridades de transparencia, a pesar de que la LTBG no establezca un modelo definido y que se otorgue un amplio margen de configuración a los legisladores, la lectura sistemática de la legislación administrativa conlleva a la necesidad de que el órgano de control competente para la resolución de las reclamaciones sustitutivas del régimen ordinario de recursos debe tener carácter colegiado, según lo establecido por el art. 112 LPAC. Algunas autoridades de transparencia incumplen este requisito ya que la normativa reguladora asigna la citada competencia a un órgano unipersonal. La pluralidad de opiniones y la necesaria deliberación del modelo colegiado resulta en cualquier caso preferible, aunque sea necesario adoptar las precauciones necesarias para evitar que el órgano colegiado pueda ser "capturado" por la lógica del sistema partidocrático de cuotas. 
Por último, cabe avisar que aún existiendo el reconocimiento de la independencia y el blindaje de los miembros de las autoridades de transparencia contra las interferencias e intereses ajenos a la legalidad y el interés general, sin la disposición de los medios materiales y personales necesarios no es posible hacer efectiva dicha independencia ni realizar las funciones encomendadas. Por lo tanto, en aquellos casos en los cuales las autoridades no disponen de la posibilidad de decidir su presupuesto y definir su plantilla, queda debilitada su autonomía y la posibilidad efectiva de poder realizar su misión institucional. Asimismo las referencias indeterminadas a la redistribución interna de medios económicos y humanos en contextos de no incremento del gasto suponen un claro riesgo de infradotación de recursos.

\section{REFERENCIAS}

ARÉVALO GUTIÉRREZ, Alfonso; MARAÑON GÓMEZ, Raquel (Dirs.). El régimen jurídico de los sectores de actividad de la Comunidad de Madrid. Madrid: Dykinson, 2017.

BALLBÉ, Manuel, MARTÍNEZ, Roser. Law and Globalization: Between the United States and Europe. ROBALINO-ORELLANA, Javier, RODRÍGUEZ-ARANA MUÑOZ, Jaime (Eds.) Global Administrative Law. Towards a Lex Administrativa. Cameron: Cameron May, 2010.

BARTLE, Ian, VASS, Peter. "Self-Regulation within the Regulatory State: Towards a New Regulatory Paradigm? Public Administration, v. 85, n. 4, pp. 885-905, oct./dez. 2007.

BELARRA GORROCHATEGUI, Javier. Los consejos de transparencia autonómicos en España: ¿Marketing político o vectores de buen gobierno?. Revista Internacional de Transparencia e Integridad, Barcelona, n. 6, p. 1-13, ene./abr. 2018.

BERMEJO LATRE, José Luis, CASTEL GAYÁN, Sergio (Eds.) Transparencia, participación ciudadana y administración pública en el siglo XXI. Zaragoza: Gobierno de Aragón, Departamento de Hacienda y Administración Pública, 2013.

BERNARDÍ GIL, Xavier. Una visió general de la Llei 19/2014, del 29 de desembre, de transparència, accés a la informació pública i bon governo. Activitat Parlamentària. Barcelona, n.28, p. 53-71, mai. 2015.

BLANES CLIMENT, Miguel Ángel. La Transparencia informativa de las administraciones públicas: el derecho de las personas a saber y la obligación de difundir información pública de forma activa. Navarra:Thomson Reuters Aranzadi, 2014.

CARMONA GARIAS, Silvia. Nuevas tendencias en la participación ciudadana en España: ¿socializando la gestión pública o socializando la responsabilidad política? A\&C - Revista de Direito Administrativo \& Constitucional, Belo Horizonte, ano 16, n. 66, p. 29-60, out./dez. 2016. 
CAPDEVILA PONCE, Gemma, SOLERNOU VIÑOLAS, Àgata. El sistema de garanties previst en la Llei de transparència, accés a la informació i bon govern. Activitat Parlamentària, Barcelona, n. 28, p. 86-104, 2015.

COTINO HUESO, Lorenzo. El reconocimiento y contenido internacional del acceso a la información pública como derecho fundamental. UNED. Teoría y Realidad Constitucional, Barcelona, n. 40, p. 279-316, jan./mai. 2017.

CHICO DE LA CÁMARA, Pablo (Coord.). Una propuesta para la introducción en nuestro sistema administrativo y tributario de medidas alternativas de resolución de conflictos (ADR). Madrid: Instituto Nacional de Administración Pública (INAP), 2017.

DE LA NUEZ SÁNCHEZ CASCADO, Elisa. Comentario al artículo 33. In: DE LA NUEZ SÁNCHEZ CASCADO; Elisa, TARÍN QUIRÓ, Carlota (Coords.). Transparencia y buen gobierno. Comentarios a la Ley 19/2013, de 9 de diciembre, de Transparencia, Acceso a la Información Pública y Buen Gobierno. Madrid: La Ley-Wolters Kluwer, 2014.

FORTINI, Cristiana; SHERMAM, Ariane. Corrupção: causas, perspectivas e a discussão sobre o princípio do bis in idem. Revista de Investigações Constitucionais, Curitiba, vol. 5, n. 2, p. 91-112, maio/ago. 2018.

FUENTES I GASÓ, Josep Ramon. La función de regeneración democrática local de los funcionarios de habilitación con carácter nacional. Revista de Estudios de la Administración Local y Autonómica, Madrid, n. 4, p. 9-39, jul./ dic. 2015.

GIMENO FELIU, José Maria. Corrupción y seguridad jurídica. La necesidad de un marco normativo de las decisiones públicas anclado en los principios de integridad y transparencia. Revista Internacional de Transparencia e Integridad, Madrid, n. 9, p. 1-17, ene./abr. 2019.

GUICHOT, Emilio (Coord). Transparencia, acceso a la información pública y buen gobierno. Estudio de la Ley 19/2013, de 9 de diciembre. Madrid: Tecnos, 2014.

HARDEN, lan. Regulating Government. The Political Quartely, London, v. 66, issue 4, p. 299-306, oct./dez. 1995.

HOOD, Christopher; JAMES, Oliver; JONES, George; SCOTT, Colien; TRAVERS, Tony. Regulation Inside Government. Waste Watchers, Quality Police, and Sleaze-busters. Oxford: Oxford University Press, 1999.

INSTITUTO NACIONAL DE ADMINISTRACIÓN PÚBLICA (INAP). La normativa autonómica en materia de derecho de acceso a la información pública. Madrid: Instituto Nacional de Administración Pública (INAP), 2016.

JIMÉNEZ ASENSIO, Rafael. Instituciones de garantía de la transparencia. El Cronista Del Estado Social y Democrático de Derecho, Madrid, n. 68, p. 60-75, 2017. 
KAYE, Robert. Regulating Parliament: the regulatory state within Westminster. Discussion Paper 13, Centre for Analysis of risk and regulation, LSE, p. 1, Jun. 2003. Disponible en: <http:// eprints.Ise.ac.uk/35999/1/Disspaper13.pdf>.

LEAL, Mônia Clarissa Hennig; MORAES, Maria Valentina de. Relações entre estado, Administração Pública e sociedade: a corrupção como fenômeno multicultural e a afetação dos direitos fundamentais. A\&C - Revista de Direito Administrativo \& Constitucional, Belo Horizonte, ano 18, n. 74, p. 175-192, out./dez. 2018.

LEAL, Rogério Gesta. Corrupção, democracia e mercado: horizontes turvos. Revista de Direito Econômico e Socioambiental, Curitiba, v. 8, n. 2, p. 303-329, maio/ago. 2017.

LEAL, Rogério Gesta. Estado, democracia e corrupção: equações complexas. Revista de Investigações Constitucionais, Curitiba, vol. 6, n. 1, p. 91-106, jan./abr. 2019.

LÓPEZ RAMÓN, Fernando (Coord.). Las vías administrativas de recurso a debate. Madrid: INAP, 2016.

MARTÍN DELGADO, Isaac; GUICHOT REINA, Emilio; CERRILLO I MARTÍNEZ, Agustí. Configuración legal, actuación y funciones de las autoridades de transparencia. Algunas propuestas de mejora. Barcelona-Madrid: Fundación Democracia y Gobierno Local, 2019.

MARTÍN DELGADO, Isaac. La configuración legal de los consejos autonómicos de transparencia: algunos riesgos para el ejercicio de su función de control. Dilemata, Madrid, n. 27, p. 288-289, abr. 2018.

MAYONE, Giandomenico. Regulating Europe. London-New York: Routledge, 1996.

MESEGUER YEBRA, Joaquín. La Transparencia en las administraciones públicas: el procedimiento de acceso a la información pública. Barcelona: Bosch, 2013.

MULGAN, Richard. Holding power to account: accountability in modern democracies, Basingstoke: Palgrave Macmillan, 2003.

ORTEGA, David. Retos de la libertad de información. Madrid: Dykinson, 2017.

OTERO PARGA, Milagros María. El compromiso con la transparencia: Especial referencia a la realidad gallega. Derechos y Libertades: Revista del Instituto Bartolomé de las Casas, Madrid, n. 39, p. 308-309, jun. 2018.

OTERO PARGA, Milagros María. Transparencia e información publica. Revista Española de la Transparencia, Madrid, n. 4, p. 66-86, sep. 2017.

PERLINGEIRO, Ricardo; DÍAZ, Ivonne; LIANI, Milena. Princípios sobre o direito de acesso à informação oficial na América Latina. Revista de Investigações Constitucionais, Curitiba, vol. 3, n. 2, p. 143-197, maio/ago. 2016. 
PIÑAR MAÑAS. Transparencia y derecho de acceso a la información pública: algunas reflexiones en torno al derecho de acceso en la Ley 19/2013, de transparencia, acceso a la información y buen gobierno. Revista Catalana de Dret Públic, Barcelona, n. 49, p. 1-19, oct./dic. 2014.

PONCE SOLÉ, Juli; CERRILLO I MARTÍNEZ, Agustí. Innovanación en el ámbito del buen gobierno regulatorio: ciencias del comportamiento, transparencia y prevención de la corrupción. Madrid: INAP, 2017.

RALLO LOMBARTE, Artemi, La Constitucionalidad de las Administraciones Independientes. Madrid: Tecnos, Madrid, 2002.

REY MARTíNEZ, Fernando. Quod omnes tangit ab omnibus cognitum esse debet: el derecho de acceso a la información pública como derecho fundamental. Revista Jurídica de Castilla y León, Valladolid, n. 33, p. 1-19, mai 2014.

RIDAO, Joan. La regulación de la transparencia y del acceso a la información pública en la esfera autonómica: Un estudio comparado. Revista General de Derecho Constitucional. n. 19, p. 1-31, 2014.

RIDAO, Joan. La transparència i el dret d'accés a la informació pública en la llei catalana 19/2014: reflexions entorn al seu abast i al marc competencial en què s'insereix. Indret. n. 4, p. 1-37, 2015.

RODRÍGUEZ-ARANA MUÑOZ, Jaime. La Directiva Europea de Contratación Pública y la lucha contra la corrupción. Revista de Direito Econômico e Socioambiental, Curitiba, v. 8, n. 1, p. 24-56, jan/abr. 2017.

RODRÍGUEZ-ARANA MUÑOZ, Jaime; SENDÍN GARCÍA, Miguel Ángel. Transparencia, acceso a la información y buen gobierno. Comentarios a la Ley 19/2013, de 9 de diciembre, de Transparencia, Acceso a la Información Pública y Buen Gobierno. Granada: Comares, 2014.

SALVADOR MARTíNEZ, María. Partidos políticos y "autoridades independientes". Revista Española de Derecho Constitucional, Madrid, n. 104, p. 90, mai./ago. 2015.

SCHIER, Adriana da Costa Ricardo; MELO, Juliane Andrea de Mendes Hey. O direito à participação popular como expressão do Estado Social e Democrático de Direito. A\&C - Revista de Direito Administrativo \& Constitucional, Belo Horizonte, ano 17, n. 69, p. 127-147, jul./set. 2017.

SCOTT, Colin. Accountability in the Regulatory State. Journal of Law and Society, London, v. 27, Issue 1, p. 38-60, jan./jul. 2000.

SENDÍN GARCÍA, Miguel Ángel. El Consejo de transparencia y buen gobierno. Revista Jurídica de Castilla y León, Valladolid, n. 33, p. 8-25, mai. 2014.

SIERRA RODRÍGUEZ, Javier. Modelos de Organismos de Garantía de la Transparencia en las Comunidades Autónomas. Revista Española de Transparencia. n. 4, p. 87-97, 2017. 
SIERRA RODRÍGUEZ, Javier. Una crítica al diseño de los organismos de garantía del derecho de acceso en las comunidades autónomas. Revista Jurídica de Castilla y León, Valladolid, n. 45, p. 73-112, mai. 2018.

TRONCOSO REIGADA, Antonio (Dir.) Comentario a la ley de Transparencia, Acceso a la Información Pública y Buen Gobierno, Madrid: Civitas, 2017.

VALERO TORRIJOS, Julián; FERNÁNDEZ SALMERÓN, Manuel (coords). Régimen jurídico de la transparencia en el sector público: del derecho de acceso a la reutilización de la información. Navarra : Thomson Reuters Aranzadi, 2014.

VALIM, Rafael. El derecho fundamental de acceso a la información pública en el Derecho brasileño. Revista de Investigações Constitucionais, Curitiba, vol. 3, n. 1, p. 169-181, jan./abr. 2016.

VELASCO RICO, Clara. La cuestión competencial en la Ley 19/2013, de 9 de diciembre: ¿de qué margen disponen las CC.AA. en materia de transparencia, acceso a la información pública y buen gobierno? Revista jurídica de Castilla y León, Valladolid, n. 33, p. 1-34, mai. 2014.

VELASCO RICO, Clara. Reconocimiento y protección del derecho de acceso a los documentos público en Quebec: especial referencia a la Comisión de Acceso a la Información. Revista Catalana de Dret Públic, Valladolid, n. 50, p. 121-140, mai. 2015.

VILALTA REIXACH, Marc, El sistema de garantías de la transparencia y el buen gobierno en Cataluña. Revista Gobernanza, Barcelona, n. 37, p. 1-21, 2015. 